\title{
Discussion Paper No. 16-075 \\ Does Energy Policy Hurt International Competitiveness of Firms? \\ A Comparative Study for Germany, Switzerland and Austria
}

Christian Rammer, Sandra Gottschalk, Michael Peneder, Martin Wörter, Tobias Stucki, and Spyros Arvanitis

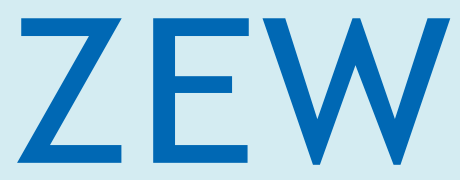

Zentrum für Europäische Wirtschaftsforschung $\mathrm{GmbH}$

Centre for European

Economic Research 


\section{Discussion Paper No. 16-075 \\ Does Energy Policy Hurt International Competitiveness of Firms? A Comparative Study for Germany, Switzerland and Austria}

Christian Rammer, Sandra Gottschalk, Michael Peneder, Martin Wörter, Tobias Stucki, and Spyros Arvanitis

Download this ZEW Discussion Paper from our ftp server:

http://ftp.zew.de/pub/zew-docs/dp/dp16075.pdf

Die Discussion Papers dienen einer möglichst schnellen Verbreitung von neueren Forschungsarbeiten des ZEW. Die Beiträge liegen in alleiniger Verantwortung der Autoren und stellen nicht notwendigerweise die Meinung des ZEW dar.

Discussion Papers are intended to make results of ZEW research promptly available to other economists in order to encourage discussion and suggestions for revisions. The authors are solely responsible for the contents which do not necessarily represent the opinion of the ZEW. 


\title{
Does Energy Policy Hurt International Competitiveness of Firms? A Comparative Study for Germany, Switzerland and Austria
}

\author{
Christian Rammer ${ }^{*}$, Sandra Gottschalk ${ }^{1}$, Michael Peneder ${ }^{2}$, Martin Wörter $^{3}$, \\ Tobias Stucki ${ }^{3}$, Spyros Arvanitis ${ }^{3}$
}

Draft version, November 2016

\begin{abstract}
This paper investigates the impact of energy policies on the export performance of firms. There has been a long policy debate on potentially negative impacts of cost-increasing energy policies on international competitiveness. We use firm-level data from three countries with similar industry structure but different energy policies: Germany, Switzerland, and Austria. We rely on firm manager assessments on the relevance of energy policy (in terms of taxes, regulations, standards, subsidies and demand stimulation) for their firm operation and link data on the adoption and development of new energy technologies. Regression analyses and matching approaches both show very few impacts of energy policy on export performance, suggesting that either policy impacts on firms' cost are negligible in the period of study (2012 to 2014) or likely negative impacts are balanced by the adoption of new technology.
\end{abstract}

Keywords: Energy policy, technology adoption, competitiveness, export, matching approach JEL classification: O33, Q48, Q55, F14, F18

1 Centre for European Economic Research (ZEW), Mannheim, Germany

2 Austrian Institute of Economic Research (WIFO), Vienna, Austria

3 ETH Zurich, KOF Swiss Economic Institute, Zurich, Switzerland

* Corresponding author: rammer@zew.de

This research was sponsored by the National Research Programme (NRP) 71 "Managing Energy Consumption" of the Swiss National Science Foundation (SNF) and by the Austrian Science Fund (FWF). 


\section{Introduction}

There is a long debate on the role of energy policy for firm competitiveness. On the one hand, energy policy is often seen as a factor that can increase production costs and lower international competitiveness. This view is particularly linked to energy policy that aims at reducing environmental impacts of energy consumption, e.g. through energy taxes, regulation, emission trade schemes or measures to raise energy efficiency or switching to renewable energy sources (Jaffe et al. 1995). On the other hand, energy policy might provide a dynamic comparative advantage, if firms learn early to respond to future challenges in energy supply and use. This perspective is linked to the so-called Porter Hypothesis (Porter 1990, Porter and van der Linde 1995). It stresses a likely positive role of environmental policy on firm competitiveness, if policy encourages innovation and the adoption of new technologies, giving firms a head advantage over competitors.

Most studies that deal with the relation between energy-related policies and competitiveness focus on environmental policy in general, and often on regulations of end-ofpipe approaches to reduce environmental externalities of energy production and consumption (see Cohen and Tobb 2015, Horvathova 2010, Iraldo et al. 2011). This study focuses on energy policy, which is a policy field that touches both environmental policy (reducing negative environmental externalities) and resource policy (securing sufficient supply of resources at affordable cost). Energy policy does not only affect firms through higher costs for complying with policy regulation but may also provide competitive advantages, if policy results in lower costs of energy use, e.g. by increasing efficiency or switching energy production to sources with a slower increase in price.

The main interest of this paper is on competitiveness impacts of energy policy, using export performance as a key indicator for international competitiveness of firms. We compare firms from three European countries that are characterised by similar economic structures but somewhat different approaches in energy policy: Germany, Switzerland, and Austria. All three countries are highly open and highly internationalised economies with a strong manufacturing sector, including some highly energy-intensive production. Policy debates in all three countries often highlight the role of energy costs as a main determinant of international competitiveness. 
This is particularly true in Germany where the government provides subsidies for the adoption of renewable energy production that are financed through higher electricity prices.

We employ a broad concept of energy policy, including energy taxes, energy-related regulation, energy-related standard setting and voluntary agreements, government subsidies for developing or adopting 'green' energy technologies (which either increase energy efficiency or promote the use of renewable energy sources), and demand-side impacts of policy such as demand for energy-efficient products. In contrast to other firm-level studies, we measure the relevance of energy policy through a firm-specific assessment for each policy area, hence avoiding a selection bias if policy impact is only measured for firms directly affected by policy (see Rexhäuser and Rammer 2014). We consider both (potentially negative) cost-related and (potentially positive) technology-related impacts of energy policy. The empirical analysis rests on a unique firm-level data set. Based on a common methodology and a uniform questionnaire, a survey of a representative sample of manufacturing and service firms from Germany, Switzerland, and Austria has been conducted in 2015. The data allow both to identify the role of different energy policy approaches for firm operations, and the development and adoption of green energy technologies.

We employ both standard regression modelling techniques and a semi-parametric matching approach and perform a series of robustness checks. All results indicate that energy policies do not significantly affect the export performance of firms, neither positive nor negative. We also do not find country-specific differences in the impacts of energy policy. Our results suggest that potential negative effects from cost increase balance out with potential positive impacts from technology adoption triggered by energy policy. However, the results suffer from a cross-section approach. Since energy policy in all three countries has been following a rather stable approach over the past fifteen years or so, it is highly likely that firms have adjusted to this policy environment so that no policy impacts can be observed in the short time window we have been looking at (2012 to 2014).

\section{Hypotheses}

Energy policy in Europe is by and large following three main objectives: decreasing the environmental impact of energy production and consumption by shifting energy sources towards low-carbon or no-carbon sources; increasing the efficiency of energy consumption; and securing 
a stable supply of energy. These policy goals often come at higher costs for energy users. This is particularly the case in Germany today. Government support for carbon-free, renewable energy sources (wind, solar) is funded by increasing energy prices (EEG). In addition, energy taxes are used to stimulate a more efficient use of energy while regulations (e.g. emission limits for production activities) force firms to use up-to-date technologies. In order to secure a stable energy supply, reserve capacities are built up, the cost of which is allocated to energy prices. The result of these policies is higher energy costs for firms which may reduce the competitiveness of their products particularly on international markets, where they have to compete over firms operating under a different energy policy setting.

But Porter and van der Linde (1995) stressed that such policies do not necessarily have to harm industry. They argue that energy policy (or environmental policy in general) can have positive impacts on competitiveness by urging firms to adopt new technologies early that later become a global standard (lead-time advantages). In addition, energy policies can promote innovation and enhance competitiveness by reducing uncertainty as regulation and standards can narrow the scope of future technology development. By generating higher demand for green technology they provide additional incentives for technology producers, while mobilising parallel innovation activities by many firms will increase knowledge spillovers.

In this paper, we attempt to analyse the impacts of energy policy on firm competitiveness while considering the role of green energy technology adoption. We focus on export performance as a measure of firm competitiveness. A firm's export performance informs about the competitiveness of products on markets where firms that operate under different energy policy environments meet. In case a national energy policy raises production costs of firms higher than energy policies of other countries do, export performance will worsen. However, if national energy policies stimulate the development and adoption of green energy technologies, positive effects on exports may emerge, either through providing an innovation advantage on export markets, or through lowering energy costs (Ambec et al. 2013).

Figure 1 illustrates the relations between energy policy, green energy technologies, and export performance. We distinguish five types of energy policies: (a) energy-related taxes and 
fees; (b) regulations on the energy use such as emission ceilings or emission certificates ${ }^{1}$; (c) standards and voluntary agreements on energy technologies, energy-efficiency goals or emission goals; (d) subsidies for developing and adopting green energy technologies; and (e) policies that raise demand for energy-efficient products or products based on green energy. While the first two types of policies are likely to raise a firm's unit costs and hence limit export performance, the last two policies tend to promote exports by either increasing energy-efficiency or by increasing sales of products related to green energy technologies. For standards and voluntary agreements, the likely effect on firms' costs is ambiguous and will depend on the exact nature of standards and voluntary agreements. Standards can reduce uncertainty and lower adoption costs for the firm but may also induce adaptation costs to comply with new standards. Voluntary agreements may be designed in a way that the costs for firms to comply with the targets set in these agreements are minimised compared to alternative mechanisms for meeting the targets.

Energy policy can positively affect the development of new green energy technologies as well as the adoption of such technologies (see Jaffe and Palmer 1997, Gallagher et al. 2012, Linn 2008, Newell et al. 1999, Popp et al. 2010, Wevant 2011). Technology development and adoption may be aimed at complying with regulation requirements or reducing energy demand in order to limit energy tax burden (see Ley et al. 2016, Horbach et al. 2012). At the same time, standards, voluntary agreements and subsidies may also spur both the development of new technologies and their adoption. Demand for energy-efficient products may directly stimulate the development of such products, but may also have an impact on adoption of green energy technologies if a greener (more energy-efficient) production of products is valued by customers.

With respect to export performance, the development of green energy technologies can provide an export advantage if this technology is demanded in other countries to meet similar energy policy targets. But if energy policy favours idiosyncratic technologies, there might be a negative export impact. Following the analysis of Beise and Rennings (2005), we expect a positive influence on export performance. For the adoption of green energy technologies, a positive impact on exports may mainly occur if firms' become more cost competitive as a result from increased energy efficiency. But green energy technology adoption may also have a direct

\footnotetext{
${ }^{1}$ In the period covered by this study, which is 2012 to 2014, the European carbon trading scheme had little impacts on energy costs of firms owing to the abundance of carbon certificates and the resulting low price for carbon emission rights.
} 
positive effect on export performance if firms can benefit from offering products based on 'green technologies'. There might be a negative impact, however, if the costs of adoption are higher than the gains from green produced products, e.g. if firms will have to increase product prices to fund adoption and price elasticity of demand is high. Hence the direct effect of energy technology adoption on export performance remains ambiguous.

Figure 1: Conceptual framework of the relations between energy policies, green energy technologies, and export performance

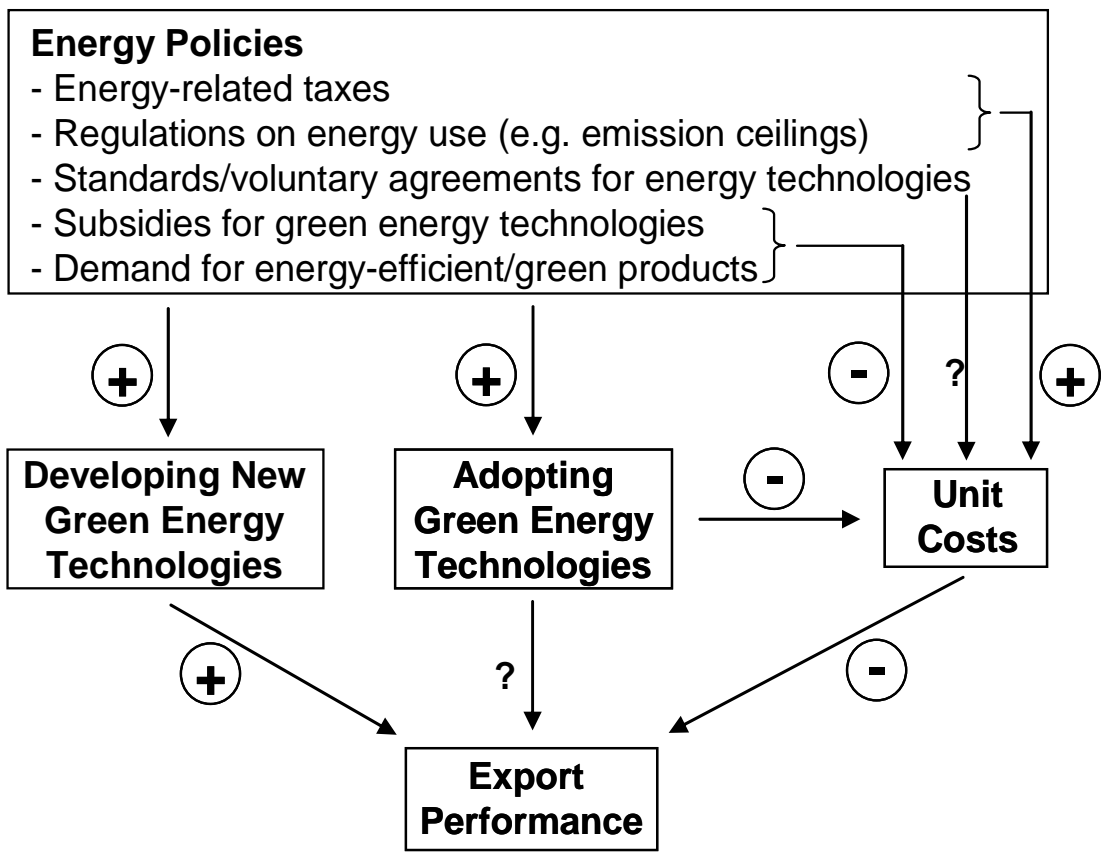

Figure 1 suggests that energy policy will have a positive impact on export performance if it stimulates firms to develop and/or adopt green energy technologies, provided that technology adoption lowers energy costs more than a corresponding rise in energy costs due to policy. Contrary, energy policy may negatively affect export performance, if it does not lead to the adoption of more energy-efficient technologies but only raises energy costs of firms. From Figure 1 it is also obvious that the positive and negative impacts of energy policies may balance out. This gives our three main hypotheses:

H1a: Energy policy has a negative impact on export performance if (all other things being equal) it raises unit costs of firms, e.g. through taxes or regulatory requirements. 
H1b: Energy policy has a positive impact on export performance if (all other things being equal) it lowers unit costs of firms, e.g. through subsidies or raising demand.

H2: $\quad$ Energy policy has a positive impact on export performance if (all other things being equal) energy policy stimulates firms to develop or adopt green energy technologies.

H3: Energy policy has a neutral impact on export performance if (all other things being equal) an increase in energy costs is balanced by a higher energy-efficiency as a result of energy technology adoption.

Given the variety of energy policies it is unlikely to identify a single policy impact since the different types of policy intervention - taxes, regulation, standards, voluntary agreements and demand incentives - are likely to have different impacts on technology adoption and energy prices. In addition, policy impacts will differ by country as countries have implemented different types of energy policies. In order to investigate these impacts, we first run regression analysis and interact energy policy variables with country and with the firm's energy technology adoption and development activities. In a second step, we perform a matching analysis and compare the export performance of similar firms from each country that are similarly affected by energy policy and show the same energy technology adoption and development activities.

\section{Energy Policy in Germany, Austria and Switzerland}

Energy policies differ significantly across the three countries considered in this study. in Germany, energy policy has been characterized in the past 25 years by a strong focus on promoting renewable energies (Lehr and Lutz 2016). Renewable energy sources, particularly biomass, solar and wind energy, are expected to substitute electric energy production from nuclear power which is to fade out by 2022 . At the same time, a growing share of renewable energy sources should help reaching the ambitious low-carbon targets of the German government (-40\% by 2020 as compared to the 1990 level, $-80 \%$ by 2050; see BMWi 2012, Lutz et al. 2014, Pregger et al. 2013). The Federal Government has introduced a series of laws and regulations to stimulate the shift in energy sources towards renewable energy and higher energy efficiency. In 1991, the Electricity Feed-in Act obliged electric utility companies to take electric energy from renewable sources at a guaranteed feed-in tariff from local and regional renewable energy producers. In 2000, the Act was succeeded by the Renewable Energy Act. The fixed feed-in tariff 
was set at a level that guaranteed profitable production and was reduced in regular intervals in order to stimulate efficiency improvements (Büsgen and Dürrschmidt 2009). The additional costs for utility companies are passed on to consumers (both households and enterprises) through a special item (renewable energy surcharge) in the electricity bill (Nolden 2013). Energy-intensive industries as well as firms with substantial own electricity production are partly exempted from the surcharge. For producers of renewable energy technologies, the legislation provided them with a home market advantage and led to the emergence of an innovative industry (Cantner et al. 2016, Lauber and Jacobsson 2016, Yu et al. 2016, Welfens and Lutz 2012). For electricity consuming firms, the renewable energy policy in Germany resulted in a constant increase in electricity prices and provided an incentive to invest into own electricity producing facilities based on renewable energy (particularly photovoltaic energy and biomass) (Lehr et al. 2009, 2012, Lipp 2007, Frondel et al. 2010). The trend to increasing electricity prices has been reinforced by an ecological tax reform in 1999, including the introduction of a new electricity tax. In addition, the petroleum tax has been redesigned to provide more incentives for investment in energy-saving vehicles.

Further energy-related policy measures in Germany include the CO2 Building Rehabilitation Programme which provided incentives for energy-efficient building refurbishment (Rosenow 2013). The programme is regarded as highly effective, having incentivized innovation both for building technology producers and house owners, including firms (Schroeder et al. 2011, Kuckshinrichs et al. 2010, Kronenberg et al. 2012, Galvin 2012). The German Federal Government is also running several R\&D programs that foster the development of energy-saving technologies, The Federal Government's 6th Energy Research Programme (2011-2016) focuses on energy saving and energy efficiency, wind energy, photovoltaic, solar technology, bio-energy, and nuclear fusion. The annual volume of R\&D funding through this program targeting both firms and public research organisations amounts to more than 0.8 billion $€$ (BMWi 2016). There are no large-scale voluntary agreements on energy saving or energy efficiency on a crossindustry level in Germany, though individual industries such as the chemical industry or the automotive have been following such an approach.

In Austria, energy always ranked high on the policy agenda. Energy intensive sectors have a high share in manufacturing output and mainly serve international markets, hence energy costs have always been a key issue for these industries. While domestic renewable energy from hydraulic power offers a cheap energy source and provides a comparative advantage to energy 
intensive production, increasing energy efficiency has become a main focus of energy policy (Köppl and Schratzenstaller 2015). The Energy Efficiency Law is the main regulatory approach in this respect. It came into force at the beginning of 2015, adopting EU guidelines that demand energy efficiency gains of 20 percent until 2020 (relative to 2005). It aims for a combination of regulatory rigor and dynamic incentives through a combination of bureaucratic control and (indirect) market mechanisms. At its core, energy suppliers (except small ones) must prove concrete measures to achieve annual efficiency gains of 0.6 percent relative to their previous year's total energy sales. These efficiency gains may originate either from their own operations or from its customers and depend on the ratio of energy inputs to output (i.e., not on total energy use). Missing the target triggers a compensatory penalty, which is paid to a fund that promotes energy saving activities. While energy using firms are not directly charged for missing the target, they are allowed to sell their efficiency measures to their energy supplier. There is no regulatory protection against suppliers discriminating prices to the disadvantage of firms that cannot offer such savings. The law commands large companies either to install a proper energy management system, or to have an energy audit every four years. In addition to the Energy Efficiency Law, the Austrian tax authorities collect taxes and levies on the use of electricity, fossil fuels (petroleum, natural and liquid gas) and coal, which are generally based on physical units and not market prices. Tax rates differ by the type of energy source. There is a ceiling for energyintensive firms in manufacturing production (Kletzan-Slamanig and Köppl 2016), which was raised in 2004 from $0.3 \%$ to a maximum of $0.5 \%$ of value added.

The Austrian Government offers public subsidies for developing and adopting green energy technologies. The Austrian Research Promotion Agency (FFG), which is the national funding agency for industrial research and development, runs a program for "energy research" since 2008, providing grants for R\&D projects. The adoption of energy-saving technologies is supported through the Environmental Promotion scheme which offers low-interest loans. Both Austria and Germany participate in the EU CO2 emission trading scheme, which has been considerably reshaped for the period 2013 to 2020. While in general, the free allocation of emission permits will continuously decrease and be replaced by competitive auctions, sectors that are particularly exposed to "carbon leakage" remain exempted and will benefit from the undiminished free allocation of emission rights.

In contrast to Germany and Austria, Switzerland has rather few policy measures to promote the development and adoption of energy-related technologies. The Swiss framework is 
characterized by market incentives and voluntary agreements while there are only a few important targeted policies (see Stucki and Woerter 2016, Pellegrin and Woerter 2016). During the reference period of our study (2012-2014), a CO2-tax (levy; since 2008) was in place that was part of the first commitment period of the Kyoto protocol and a Swiss emission trading system (for heavy polluters) — which is still very narrow-started in 2013. There is also an emission regulation for passenger cars - similar to the EU-regulations - which has been effective since 2012. A feed-in-tariff system has been already introduced in 1998 and a (subsidy) program for adoption of green technologies in the building sector, started in 2010. There are also regulations concerning labelling, promotion and installation of renewable energy plants. Public subsidies are available in form of a technology fund to promote innovative technologies that reduce greenhouse gas emissions and the consumption of resources. It also supports the use of renewable energy and an increase in energy efficiency. There are also subsidies for basic research and applied R\&D in form of pilot plants for economical and efficient use of energy and use of renewable energies.

Table 1: Relevance of energy policy for firms in Germany, Switzerland and Austria

\begin{tabular}{|c|c|c|c|c|c|c|c|c|}
\hline \multirow{2}{*}{$\begin{array}{l}\text { Share in all } \\
\text { firms in \% }\end{array}$} & \multicolumn{2}{|c|}{ Germany } & \multicolumn{2}{|c|}{ Switzerland } & \multicolumn{2}{|c|}{ Austria } & \multicolumn{2}{|c|}{ Total } \\
\hline & $\begin{array}{r}\text { somewhat } \\
\text { relevant }\end{array}$ & $\begin{array}{r}\text { highly } \\
\text { relevant }\end{array}$ & $\begin{array}{r}\text { somewhat } \\
\text { relevant }\end{array}$ & $\begin{array}{r}\text { highly } \\
\text { relevant }\end{array}$ & $\begin{array}{l}\text { somewhat } \\
\text { relevant }\end{array}$ & $\begin{array}{r}\text { highly } \\
\text { relevant }\end{array}$ & $\begin{array}{r}\text { somewhat } \\
\text { relevant }\end{array}$ & $\begin{array}{r}\text { highly } \\
\text { relevant }\end{array}$ \\
\hline Energy taxes ${ }^{1)}$ & 34.3 & 18.5 & 30.8 & 10.9 & 27.2 & 15.7 & 32.7 & 17.1 \\
\hline $\begin{array}{l}\text { Energy-related } \\
\text { regulation }\end{array}$ & 22.8 & 8.3 & 24.5 & 9.0 & 23.7 & 1.5 & 23.2 & 7.3 \\
\hline $\begin{array}{l}\text { Energy-related } \\
\text { standards/voluntary } \\
\text { agreements }\end{array}$ & 16.7 & 6.2 & 21.3 & 6.3 & 20.4 & 3.5 & 17.8 & 5.8 \\
\hline $\begin{array}{l}\text { Subsidies for } \\
\text { energy } \\
\text { technologies }\end{array}$ & 21.1 & 10.0 & 19.8 & 7.2 & 22.6 & 6.2 & 21.2 & 9.0 \\
\hline $\begin{array}{l}\text { Demand for energy- } \\
\text { efficient products }\end{array}$ & 18.7 & 6.6 & 20.0 & 6.0 & 20.9 & 5.0 & 19.2 & 6.3 \\
\hline
\end{tabular}

1) with respect to the domestic energy policies.

Source: KOF/WIFO/ZEW: Energy technology survey 2015, weighted results.

Despite the quite different energy policy environments in Germany, Switzerland and Austria, firms from the three countries perceive the energy policy environment in their country rather similar. German firms more often report energy taxes to be highly relevant for their business (19\%) while only $11 \%$ of Swiss firms consider energy taxes highly relevant (see Table 1). Energy regulations are most often quoted as relevant by Swiss firms, while firms from Germany and Austria show higher shares when it comes to subsidies for energy technologies, 
reflecting the widespread support activities of both governments in this area. For the demand for green energy, which is not a direct characteristic of energy policy but can be strongly affected by energy policy, we find very similar shares of firms quoting demand for green energy as being relevant for the business for each country. As demand includes customers from abroad, which are subject to energy policies of other government, the similar results may reflect similar export markets of the three economies.

\section{Data and Empirical Strategy}

We use data from a firm survey that was conducted in each of the three countries studied in this paper during 2015 based on a uniform questionnaire and common survey methodology. The survey covered both manufacturing and services. It collected information on energy consumption, the role of energy policy for a firm's operation, and the development and adoption of energy-related technologies as well as information on various firm characteristics (including exports) and the firms' market environment. In Switzerland and Austria, the survey was conducted as a stand-alone survey by the Swiss Economic Institute (KOF) and the Austrian Institute of Economic Research (WIFO) while in Germany it was part of the annual innovation survey (the German contribution to the Community Innovation Survey of the EU) conducted by the Centre for European Economic Research (ZEW). Details on the survey and its methodology can be found in Arvanitis et al. (2016a). The net sample of the survey includes 4,634 observations, 49\% of them are German firms, 39\% Swiss firms and 12\% Austrian firms. On average, the firms in our sample have 269 employees (median: 38 employees). $50.4 \%$ of the firms belong to the manufacturing sector (including energy and water supply and waste management activities) and $49.6 \%$ to services (including construction services).

The information on firms' activities related to green energy technologies refers both to the introduction of any new energy-related technologies during 2012 and 2014 for in-house use ("adoption"), and to the development of such technologies for selling the technology on the market during the same period ("development"). Five areas of energy technologies are distinguished: (1) production technologies, (2) information and communication technologies, (3) transport and logistics technologies, (4) building and heating technologies, and (5) green energygenerating technologies from renewable sources. As the area of energy technology activity is strongly driven by a firm's industry and market (e.g. manufacturing firms typically focus on 
production technologies, firms in trade and transport on logistics technologies, and service firms on building and heating technologies, and energy technology development mainly takes place in firms specialised in the respective field of technology), we do not separate between the five areas but consider any firm as adopter or developer if in at least one area a new energy technology has been introduced or developed.

The identification of the relevance of different energy policies at the firm level is hardly possible through 'objective' data that can be observed from public sources. We hence rely on survey and ask managers to rate the relevance of different energy policies for their firm's business on a three-point Likert scale (see Johnstone et al. 2012, Lanoie et al. 2011, Stucki and Woerter 2016, Veugelers 2012 for similar procedures). While subjectivity of survey data may limit comparability across firms (Bertrand and Mullainathan 2009), there are two advantages for our research design. First, we are able cover all types of policies on the same measurement level. This would be hardly possible if external data for different policy areas such as tax rates, emission trading certificates, participation in voluntary agreements or receipt of government subsidies would be employed. Second, we can establish the relevance of energy policies also for firms that might not be directly targeted by a certain policy. This overcomes the frequent difficulty that arises from the fact that different policies typically target different firms, that policies may exist at multiple levels (e.g. federal and local), and that monitoring and enforcement are imperfect (Millimet and Roy 2015, Levinson 2008, Shadbegian and Wolverton 2010, Xing and Kolstad 2002).

In order to establish whether the adoption of energy technologies has been related to energy policy (in order to test H2), we refrained from putting forward a direct question on that link (e.g. as done in the 2008 Community Innovation Survey, see Horbach et al. 2012, Rexhäuser and Rammer 2014) but rather asked managers whether increasing energy efficiency has been a key motive for adopting new energy technologies, or whether it was a side effect. If firms had introduced new energy technologies in order to increase energy efficiency and had at the same time reported earlier in the questionnaire that certain energy policies were relevant for their business operations, we would regard energy technology adoption in these firms as-directly or indirectly - related to these energy policies. For testing $\mathrm{H} 3$, we can utilise information on whether energy technology adoption led to an increase in energy-efficiency (and hence lowered unit cost of production) by directly asking all firms that introduced new energy technologies during 2012 and 2014 whether this technology adoption led to a decrease in energy consumption 
per unit of output by the end of 2014. If adoption has led to an increase in efficiency, we would expect a positive effect on export performance.

Combining motives for and cost impacts of energy technology adoption with the relevance of energy policies and considering our three hypotheses developed in section 2 gives a matrix of expected impacts of energy policy relevance and adoption of energy technologies on export performance (see Table 2). Assuming that energy taxes and energy-related regulation will increase firms' unit costs, we will expect negative impacts of firms subject to these policies, except policy-related technology adoption led to energy cost reduction. If technology adoption was not related to energy policy and increased energy efficiency, the expected impact is less clear since the side effect of energy efficiency increase may not have been related to costs that a firm has to bear in order to comply with energy policy. For energy-related standards and voluntary agreements, we do not have clear expectations as the impact of these policy measures on cost is unclear. For subsidies for energy technologies and demand for green energy, we would expect positive impacts on export performance for adopters when the key motive of adoption was increasing energy efficiency as these firms will have profited either directly (by receiving subsidies for their technology adoption) or indirectly (by a lower price of new energy technology resulting from subsidies for others). For the other group of adopters, the positive impact is less obvious if adoption was not related to a subsidies technology.

Table 2: Expected impacts of energy policy relevance and adoption of energy technologies on export performance

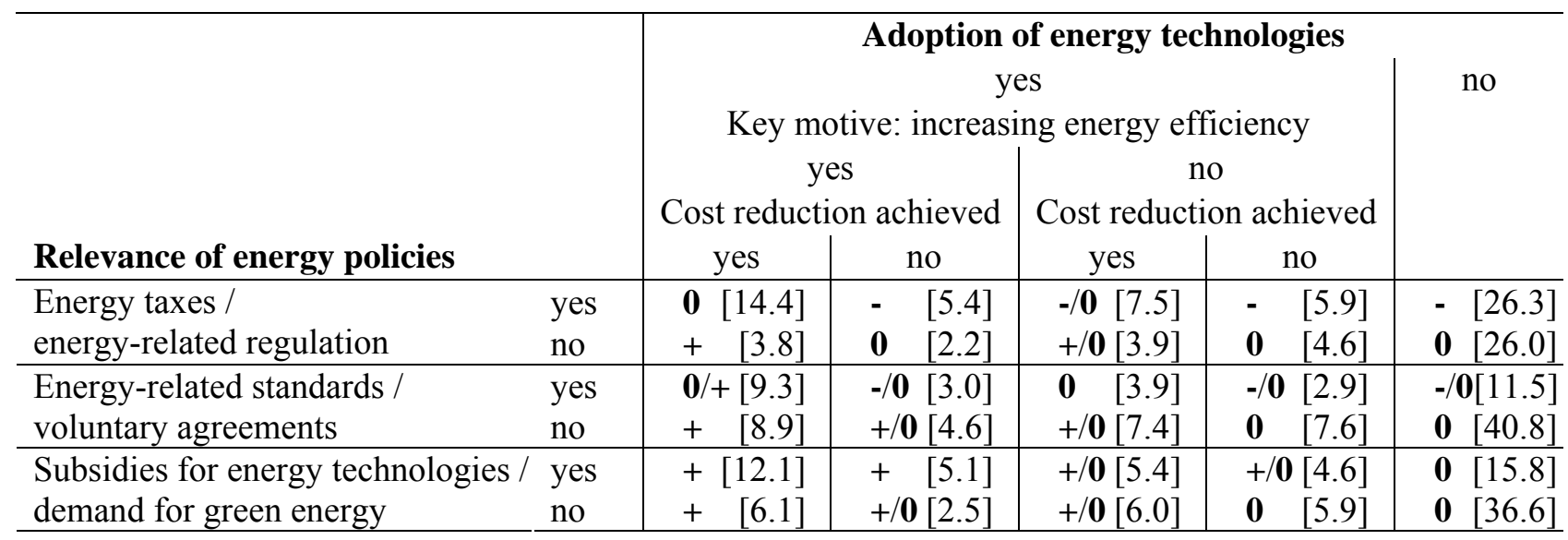

+/0/-: expected positive/neutral/negative impact on export performance.

Figures in brackets give the percentage of firms (in the net sample of surveyed firms) that fall under the respective category; percentages add up to 100 for each of the three areas of energy policies. 
When counting the number of firms in our sample showing a combination of energy policy relevance $^{2}$ and energy technology adoption motives and effects, for which we would expect a clearly positive export performance impact ('+' in Table 2), $23.3 \%$ of all firms fall in this group. ${ }^{3}$ At the same time, for $37.6 \%$ of firms we would expect clearly negative expected impacts ('-' in Table 2). Note that one and the same firm may fall into both groups (which is actually the case for $4.1 \%$ of all firms). For $30.4 \%$ of firms we would expect rather positive export impacts ('+/0') and for $24.9 \%$ rather negative ones (' $0 /{ }^{\prime}$ '). $81.4 \%$ of all firms report relevance of energy policies and energy technology adoption patterns that have been classified as neutral (' 0 ').

Export performance of firms is measured by the share of exports in total sales at the end of the three year reference period (i.e. 2014), which is applied to the questions related to the relevance of energy policies and the development and adoption of energy technologies. We use the export share in 2012 to control for a firm's initial export performance. This allows us to analyse a likely impact of energy policies and energy technology adoption on changes in export performance rather than on the level of export activities.

We employ two complementary methods for investigating likely impacts of energy policy relevance and energy technology adoption on export performance. First, we use standard regression modelling in order to determine whether energy policies and energy technology adoption affect export performance. To test our hypotheses, we combine a firm's assessment of energy policy relevance for five policy areas (taxation, regulation, standards/voluntary agreements, subsidies, demand) with the five energy technology adoption patterns shown in Table 2. This allows us to test our hypotheses across the three countries of our study by looking at cross-country differences in policy relevance, adoption patterns and export performance.

A regression approach is less suited for looking at country-specific policy effects since splitting models by countries would result in a low number of observations per model

\footnotetext{
${ }^{2}$ A policy area is considered as relevant if a firm stated that the policy was 'somewhat' or 'highly' relevant for the firm's business. We follow this measurement for policy relevance in the remainder of the paper. Considering only firms stating that a certain policy was 'highly' relevant (i.e. ignoring firms with 'somewhat relevant') produces qualitatively very similar results. In the regression analysis, we will present robustness checks for an alternative measurement of policy relevance that relies on 'highly relevant' only.

${ }^{3}$ Note that the percentages reported here cannot be calculated by summing up the percentages shown in Table 2 as firms may show the same expected effect for two or even three energy policy areas.
} 
(particularly in the case of Austria). Alternatively, one could interact policy and adoption variables with country dummies. This would result in a huge number of interaction effects and potential multicollinearity problems. We hence employ a more flexible semi-parametric matching method which basically combines propensity score stratification with a weighting scheme. The next section presents the results of the regression analysis, followed by the results of the matching approach.

\section{Regression Estimation Results on Policy Impacts}

The export performance model uses export share in $t$ as main dependent variable. As this variable is zero for all firms without any export activity (which is roughly half of our sample as the sample includes a large number of service firms and small firms), we use tobit models to consider this pile-up of zeros. In addition, we also run models using an export dummy (export activity in $t$ vs. no exports in $t$ ) and the export share in $t$ only for firms with positive exports. This informs whether policy and adoption rather affect a firm's ability to enter into export activity, or whether they change the export intensity of already exporting firms. In all models, we control for initial export performance in t-2. For robustness checks, we also consider the change in the export share between $\mathrm{t}-2$ and $\mathrm{t}$, and the change in export volume between $\mathrm{t}-2$ and $\mathrm{t}$. In order to identify likely policy and adoption effects, we need to control for other determinants of export performance, including price competitiveness, product differentiation, and a firm's resources (see Arnold and Hussinger 2010, Beise-Zee and Rammer 2006, Cassiman et al. 2010). Our control variables include product and process innovations outside of energy technologies for capturing product differentiation, size, age, and membership of a domestic or foreign company group for capturing firm resources relevant for exporting, and unit labour costs, the share of material input and relative labour productivity as measures of price competitiveness. In addition, we add energy-specific variables which may affect export performance and correlate with energy policy relevance and energy technology activities. Energy intensity in t-2 is used to control for a firm's general incentives to engage in measures to increase energy efficiency. The energy sources used by a firm are intended to capture different price developments for energy sources which may also affect the relevance of certain policies and the incentives for adopting new technologies. All models also include country and industry dummies. 
Our key variables for testing the hypotheses are energy policy relevance and the pattern of energy technology adoption with respect to whether increasing energy efficiency was a key motive, and whether the adoption actually led to an increase in energy efficiency. In addition, we consider, whether a firm has developed new energy technologies for the market (i.e. as a product innovation). Descriptive statistics for all model variables can be found in Table 6 in the Appendix. We estimate two model variants. First, we include the policy and adoption variables separately. Second, we combine the two groups of variables to investigate whether adoption and policy relevance coincides, potentially balancing likely positive and negative effects. As we have five policy areas and five adoption patterns (including no adoption), we end up with 25 combined policy-adoption variables.

The results of the first model variant are shown in Table 3 for the main model and in Table 7 and Table 8 in the Appendix for alternative model specifications. In the base model (see column 1 in Table 3), we find a statistically significant positive relationship between energy technology adoption and export performance along with a significant positive effect for firms that have developed new energy technologies for the market. We do not find any strong significant impact for any of the five policy variables. For one policy variable - demand for energy efficient products - a statistically negative effect appears, though at the $10 \%$ level of significance only. This may suggest that a policy that increased demand for energy-efficient products redirects firms to domestic markets. ${ }^{4}$ When replacing the adoption variable by two variables measuring the key motive (increasing energy efficiency or any other motive) and adding a variable whether an increase in efficiency has been achieved (column 2), it turns out that an achieved increase in energy efficiency has no impact on export performance. When combining motives and achieved efficiency impacts of energy technology adoption into four variables (using non-adopters as a reference, see column 3), we find that technology adopters that aimed at increasing energy efficiency and having met this goals perform better, but also adopters that did not aim at increasing energy efficiency through introducing green energy technologies and also did not experience any efficiency increase. For the latter group, one may assume that the adoption of green energy technologies was part of other process innovations aiming at increasing

\footnotetext{
${ }^{4}$ Note that firms were asked to assess the relevance of demand for energy-efficient products for domestic and foreign markets. We merged this information into one demand variable in order to avoid endogeneity as only exporting firms are able to provide information about foreign demand.
} 
productivity or improving the quality of processes, which had positive impacts on their export performance.

Table 3: Impact of energy policy relevance and energy technology adoption on export performance of firms: estimation results of tobit models

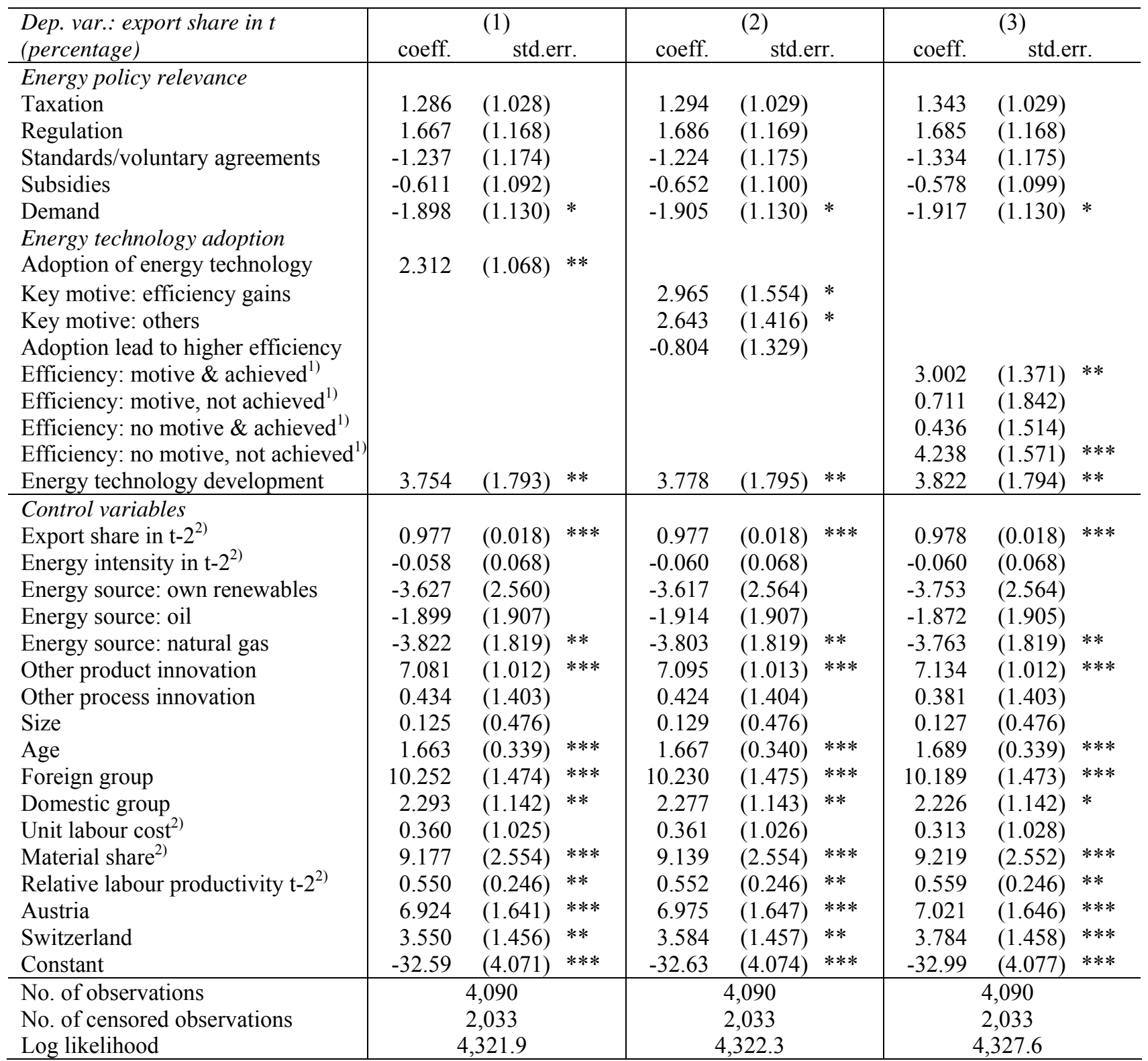

$* * *, * *, *$ : significant at the $0.01,0.05,0.1$ level.

Each model includes 25 industry dummies which are jointly significant.

1) Reference category: no adoption

2) Missing values are set to 0 and dummy variables indicating missing observations have been included.

Most of our control variables are statistically significant and show the expected signs. Naturally, past export performance is a main predictor for current export performance. Product 
differentiation through product innovation has a strongly positive export effect which confirms the results of many prior studies (see Becker and Egger 2013, Bleaney und Wakelin 2002, Wakelin 1998, Lachenmaier und Wößmann 2006, Roper and Love 2002). We do not find size effects (as the impact of size of the level of export performance is mirrored in initial export performance), while we do find positive effects for age and group membership. Unit labour cost does not affect export performance significantly, reflecting that the competitive advantage of firms from Germany, Switzerland and Austria on export markets seems to be related to quality features of their products rather than cost advantages. Firms with a high share of inputs in total sales and firms with a high productivity compared to their industry average show better export performance. We also find highly significant positive coefficients for firms from Austria and Switzerland (with Germany as reference), indicating that firms from smaller economies tend to show a higher and more rapidly increasing export share. Energy intensity shows no significant impact on export performance while firms using natural gas as an energy source show a worse export performance which may be related to a less favourable price development of this energy source in the period considered in this study (2012 to 2014).

The findings do not differ substantially if other model specifications are considered. When The results of probit regressions on the probability to export (Table 7) and OLS regressions on the export share of exporting firms (Table 8) suggest that the positive effect of energy technology adoption relates to a positive impact on the propensity to export, but not on the export share of exporting firms. The OLS regression results report a significant positive effect for energy-related regulations: firms stating that such regulations are relevant for their business show a higher export share. The results of the probit model on the probability to export (Table 7) demonstrate a statistically significant negative impact of demand for energy-efficient products. A significant negative impact of demand is also found for the model specification using the change in the export volume as export performance variable (see Table 9). All other policy variables are insignificant in that model, as are the adoption variables. For the model specification with the change in export share between 2012 and 2014 as dependent variable we do not find any significant effects, neither for policy nor for adoption variables. 
Table 4: Impact of combinations of energy policy relevance and energy technology adoption patterns on export performance of firms: estimation results of tobit models

\begin{tabular}{|c|c|c|c|}
\hline \multirow{2}{*}{$\begin{array}{l}\text { Dep. var.: export share in } t \text { (percentage) } \\
\text { Energy policy relevance \& energy technology adoption motives and impacts }\end{array}$} & \multirow[t]{2}{*}{ coeff. } & \multicolumn{2}{|c|}{ std.err. } \\
\hline & & & \\
\hline Taxation \& adoption (motive energy efficiency \& increase in efficiency) & 0.795 & $(2.024)$ & \\
\hline Regulation \& adoption (motive energy efficiency \& increase in efficiency) & 3.890 & $(2.298)$ & $*$ \\
\hline Standards/vol. agr. \& adoption (motive energy efficiency $\&$ increase in efficiency) & 0.404 & $(2.227)$ & \\
\hline Subsidies \& adoption (motive energy efficiency \& increase in efficiency) & -0.287 & $(2.077)$ & \\
\hline Demand \& adoption (motive energy efficiency \& increase in efficiency) & -2.589 & $(2.167)$ & \\
\hline Taxation \& adoption (motive energy efficiency \& no increase in efficiency) & 1.061 & $(3.299)$ & \\
\hline Regulation \& adoption (motive energy efficiency \& no increase in efficiency) & -1.534 & $(4.126)$ & \\
\hline Standards/vol. agr. \& adoption (motive energy efficiency \& no increase in efficiency) & 2.433 & $(3.770)$ & \\
\hline Subsidies $\&$ adoption (motive energy efficiency $\&$ no increase in efficiency) & 0.696 & $(3.242)$ & \\
\hline Demand \& adoption (motive energy efficiency \& no increase in efficiency) & -4.391 & $(3.742)$ & \\
\hline Taxation $\&$ adoption (other motive $\&$ increase in efficiency) & 2.963 & $(2.500)$ & \\
\hline Regulation \& adoption (other motive \& increase in efficiency) & -2.247 & $(3.212)$ & \\
\hline Standards/vol. agr. \& adoption (other motive \& increase in efficiency) & -1.411 & $(3.091)$ & \\
\hline Subsidies \& adoption (other motive \& increase in efficiency) & 2.388 & $(3.026)$ & \\
\hline Demand \& adoption (other motive \& increase in efficiency) & -4.207 & $(2.868)$ & \\
\hline Taxation \& adoption (other motive \& no increase in efficiency) & 1.683 & $(2.759)$ & \\
\hline Regulation \& adoption (motive energy efficiency, no increase in efficiency) & 6.099 & $(3.604)$ & $*$ \\
\hline Standards/vol. agr. \& adoption (other motive \& no increase in efficiency) & -1.823 & $(3.559)$ & \\
\hline Subsidies \& adoption (other motive \& no increase in efficiency) & -1.893 & $(3.131)$ & \\
\hline Demand \& adoption (other motive \& no increase in efficiency) & 2.217 & $(3.105)$ & \\
\hline Taxation \& no adoption & 1.381 & $(1.356)$ & \\
\hline Regulation \& no adoption & 1.554 & $(1.750)$ & \\
\hline Standards/vol. agr. \& no adoption & -3.169 & $(1.926)$ & \\
\hline Subsidies \& no adoption & -0.864 & $(1.778)$ & \\
\hline Demand \& no adoption & -1.078 & $(1.778)$ & \\
\hline Energy technology development & 4.203 & $(1.791)$ & $* *$ \\
\hline Control variables & & & \\
\hline Export share in $\mathrm{t}-2^{1)}$ & 0.979 & $(0.018)$ & $* * *$ \\
\hline Energy intensity in $\mathrm{t}-2^{1)}$ & -0.050 & $(0.068)$ & \\
\hline Energy source: own renewables & -3.670 & $(2.566)$ & \\
\hline Energy source: oil & -1.854 & $(1.909)$ & \\
\hline Energy source: natural gas & -3.854 & $(1.819)$ & $* *$ \\
\hline Other product innovation & 7.218 & $(1.010)$ & $* * *$ \\
\hline Other process innovation & -0.163 & $(1.351)$ & \\
\hline Size & 0.125 & $(0.476)$ & \\
\hline Age & 1.726 & $(0.338)$ & $* * *$ \\
\hline Foreign group & 10.044 & $(1.475)$ & $* * *$ \\
\hline Domestic group & 2.169 & $(1.143)$ & $*$ \\
\hline Unit labour cost ${ }^{1)}$ & 0.256 & $(1.027)$ & \\
\hline Material share ${ }^{1)}$ & 9.227 & $(2.557)$ & $* * *$ \\
\hline Relative labour productivity $\mathrm{t}-2^{1)}$ & 0.565 & $(0.246)$ & $* *$ \\
\hline Austria & 7.271 & $(1.654)$ & $* * *$ \\
\hline Switzerland & 3.594 & $(1.454)$ & $* *$ \\
\hline Constant & -31.98 & $(4.084)$ & $* * *$ \\
\hline No. of observations & & 4,090 & \\
\hline No. of censored observations & & 2,033 & \\
\hline Log likelihood & & 335.2 & \\
\hline
\end{tabular}

$* * *, * *, *$ : significant at the $0.01,0.05,0.1$ level.

Each model includes 25 industry dummies which are jointly significant.

1) Missing values are set to 0 and dummy variables indicating missing observations have been included. 
The result of our second model variant with combined policy-adoption variables produces insignificant coefficients for almost all combinations (see Table 4). ${ }^{5}$ There are only two exceptions. Firms reporting energy-related regulation as relevant and who have either introduced new energy technologies for increasing energy efficiency (and having met this goal) or who have adopted energy technologies for other purposes (and did not experience any efficiency increase), export performance is significantly higher, though only at a $10 \%$ level of significance. The first result suggests that there might be a slight positive impact of energy-related regulation on competitiveness as proposed by the Porter hypotheses: If regulation initiates effective technology adoption, the efficiency gains from new technology seems to exceed the costs of complying with the regulation.

The results of the main model have to be qualified when looking at alternative model specifications (Table 10 in the Appendix). The probit model on export probability shows a weakly significant impact of subsidies if combined with technology adoption that successfully aims at energy efficiency, and a positive effect of energy taxation if combined with technology adoption that increases energy efficiency as a side goal of adoption. For this type of adopters, a weakly significant negative effect occurs, if energy-related regulation is relevant for them. For firms that did not adopt energy technologies and are subject to energy-related regulation, we find a significant positive export performance effect, while a negative one is found if subsidies for energy technologies are relevant for them. The latter may indicate a competitive disadvantage, if their competitors used the subsidies to update their technological base. The model variants using the change in export share and the change in export volumes as dependent variables mainly produce insignificant results for the combined policy-adoption variables. We find a significant negative coefficient if demand for energy-efficient products is relevant and the firm successfully adopted energy-efficient technologies, suggesting that a policy shaping demand towards higher energy efficiency may motivate technology adopters to serve the domestic demand and reduce exports. Or to put it differently: domestic demand is more responsive to energy efficiently produced products compared to foreign markets if the regulation in foreign markets is less stringent and hence there is no willingness to pay for environmentally friendly produced

\footnotetext{
${ }^{5}$ This result also holds if policy relevance is measured in a more narrow way by only considering firms as affected by a policy if managers stated that the respective energy policy has been 'highly' significant for their business. Estimation results based on this alternative definition are shown in Table 12 in the Appendix.
} 
products. In addition, we find a positive impact of subsidies on export performance for technology adopters that did neither aim at nor achieve to increasing energy efficiency.

The results of regressions analyses suggest that energy policy, as perceived by firms, has little impacts on export performance. Firms that report high relevance of energy taxes and energy-related regulation - which both are often viewed as cost burdens for firms and potentially impeding their international competitiveness - do not show lower export performance. For regulation, we even find some positive impacts if firms adopt new energy technologies at the same time. All in all, we cannot confirm hypotheses 1 and 2 but find some evidence for our third hypothesis, i.e. that higher costs of energy policy measures are balanced by more energy efficient production. In general, energy policies in the three countries considered did not have a major impact on international competitiveness during the period considered in this study. This finding refers to the average effect across all three countries, however. The next section tries to identify likely country-specific differences in the link between energy policy, energy technology adoption and export performance.

\section{Results of a Matching Approach on Country-specific Policy Impacts}

We employ a matching approach for investigating country-specific policy impacts. The basic idea is to compare the export performance of firms from three countries Germany, Switzerland and Austria that operate under a very similar situation (in terms of their resources, their capabilities to successfully export, their energy intensity and energy sources they use, and their past export performance) and that experience the same relevance of energy policies and show the same pattern of energy technology adoption (in terms of energy efficiency as key motive and as a result of technology adoption).

As usual in matching approaches, we estimate a propensity score model and take its results for matching, using the marginal mean weighting through stratification (MMWS). MMWS is a nonparametric adjustment technique that combines propensity score stratification with a weighting scheme (Hong 2010). The treatment variables in the propensity score matching are the combinations of energy policy relevance and energy technology adoption. Due to limitations in the number of observations, we cannot consider all 25 combinations but consider the 
combinations between policy and adoption motive on the one hand, and policy and energy efficiency results of adoption on the other. The probit models for calculation propensity scores basically include the same set of variables as used in the export performance models, along with a few more variables to control for as many elements of firm heterogeneity as possible. This additional variables include a dummy for in-house R\&D activity, measures for the competitive environment of the firm (number of main competitors and an indicator on the intensity of competition), capital expenditure in $\mathrm{t}-2$, whether a change in the composition of energy sources between $\mathrm{t}-2$ and $\mathrm{t}$ resulted in a positive or negative change in energy costs per unit of output, the share of graduated employees, and whether energy shortages or fluctuations in energy prices had affected the firm's operation between $\mathrm{t}-2$ and $\mathrm{t}$.

Basis for the MMWS matching procedure are the propensity scores for each study group. The 'treatment' group includes all firms with a certain combination of energy technology adoption and relevance of a certain energy policy area while the control group consists of firms for which this combination does not apply. The propensity scores are derived from bivariate logistic regressions for each policy-adoption combination which are estimated for each of the three countries separately. Propensity scores reduce the different observation unit's set of covariates to a single score. The entire range of propensity scores is then divided into five different strata which are the quantiles of the distribution. To create comparability between the treatment and the control group, MMWS assigns weights to the units in the treatment group and the control group within each stratum such that the weighted groups depicts similar distributions of the covariates used for the propensity score estimation. The weights are marginal mean weights for each stratum and are computed as follows:

$$
\left(\mathrm{n}_{\mathrm{s}} / \mathrm{n}_{\mathrm{s}_{\mathrm{z}}}\right) \times \boldsymbol{P r}(\mathrm{Z}=\mathrm{z})=\left(\mathrm{n}_{\mathrm{s}} / \mathrm{n}_{\mathrm{s}_{\mathrm{z}}}\right) \times\left(\mathrm{n}_{\mathrm{z}} / \mathrm{n}\right)
$$

The ratio $n_{s} / n_{s_{z}}$ is the inverse of the probability to be assigned to observations in stratum $s$ in study group $z$, where $n_{s}$ denotes the number of observations in stratum $s$ and $n_{s_{z}}$ the number of observations in stratum s of study group z. $\boldsymbol{P} r(Z=z)=n_{z} / n$ is the probability of belonging to study group $z$, i.e. the share of numbers of observations in study group $z\left(n_{z}\right)$ on total $(n)$. The number $\mathrm{n}_{\mathrm{s}} \times \boldsymbol{P} \mathrm{r}(\mathrm{Z}=\mathrm{z})$ is therefore the expected number of units in stratum $\mathrm{s}$ in a completely randomized experiment where the weights would all be equal to 1 . In a randomised experiment the assignment to the treatment groups and the control group would be completely random and the distributions of all sample characteristics are equal in each study group. Hence the weighting 
scheme adjusts the observed sample to an optimal sampling design for computing treatment effects. The average treatment effects - here: firms' export activities and outcomes — can now be easily estimated by calculating the difference between the weighted mean outcomes of the treated and the control units, respectively.

The matching results show very few statistically significant country differences in the impacts of energy policy relevance and energy technology adoption on firms' export performance. Table 5 presents the results for the five areas of energy policy combined with the adoption of new energy technologies. We find a few significant negative impacts on the export intensity of export-active Swiss firms that introduced new energy technologies, when not being affected by potentially cost raising energy policies (taxation, regulation). This result suggests that the adoption of green energy technologies that is not related to policy pressure may result in too low efficiency gains compared to firms in Germany and Austria where technology adopterseven if not driven by policies - may profit from a higher level of efficiency improvements related to available new energy technologies. We also find weakly significant negative effect on the export propensity of German firms if they refrained from technology adoption and are not concerned by certain energy policies (taxation, standards/voluntary agreements, subsidies). For Swiss firms, a positive effect of demand for energy-efficient products on the export share of exporting firms shows up in case the firms did not adopt new energy technologies. For firms quoting energy policies as relevant for their business, we do not find any negative result except for Austrian and German firms stating that demand for energy-efficient products is relevant.

The overwhelmingly insignificant results remain when the relevance of energy policies is combined with the key motive of technology adoption (Table 13 in the Appendix) and with the efficiency increase resulting from technology adoption (Table 14 in the Appendix). The only negative policy impacts found in these analyses are for energy-related regulations in Austria in case firms did not adopt new energy technologies aiming at increasing efficiency, and for the demand variable in Austria if combined with technology adoption aiming at efficiency increase. While the former may hint to some cost burden of energy regulation if facilities are not upgraded, the latter can again show the market reorientation of firms if domestic demand for energyefficient products is high, as already discussed above.

One should critically note that the empirical results of our matching analysis are limited by the sometimes small number of observations for each combination, particularly in the case of Austria where for some policy-adoption combinations only 20 to 30 observations are available. 
For Germany and Switzerland, the number of observations per combination is usually close to or above 100, providing more robust results.

Table 5: Matching results on export performance by combinations of energy policy relevance and energy technology adoption, by country

\begin{tabular}{|c|c|c|c|c|c|c|c|c|c|c|}
\hline Country & $\begin{array}{l}\text { Energy } \\
\text { policy }\end{array}$ & \multirow[t]{2}{*}{$\begin{array}{l}\text { Techno- } \\
\text { logy } \\
\text { adoption } \\
\end{array}$} & \multicolumn{2}{|c|}{ Export activity in $\mathrm{t}$} & \multicolumn{2}{|c|}{$\begin{array}{l}\text { Export share in } \mathrm{t} \\
\text { (all firms) } \\
\text { Effect sign. }\end{array}$} & \multicolumn{2}{|c|}{$\begin{array}{l}\text { Export share in } \mathrm{t} \\
\text { (exporters only) } \\
\text { Effect sign. }\end{array}$} & \multicolumn{2}{|c|}{$\begin{array}{l}\text { Change in export } \\
\text { share betw. t- } 2 \text { and } t \\
\text { Effect sign. }\end{array}$} \\
\hline \multicolumn{10}{|c|}{ Energy taxes } & \\
\hline GER & yes & yes & $0.8 \%$ & 0.816 & $-0.3 \%$ & 0.813 & $-1.0 \%$ & 0.699 & $0.1 \%$ & 0.820 \\
\hline SUI & yes & yes & $-0.4 \%$ & 0.939 & $-0.7 \%$ & 0.802 & $-1.7 \%$ & 0.660 & $0.7 \%$ & 0.473 \\
\hline AUT & yes & yes & $4.0 \%$ & 0.393 & $4.7 \%$ & 0.519 & $3.2 \%$ & 0.685 & $-0.5 \%$ & 0.649 \\
\hline GER & yes & no & $-0.7 \%$ & 0.838 & $-1.2 \%$ & 0.415 & $-2.6 \%$ & 0.291 & $0.0 \%$ & 0.991 \\
\hline SUI & yes & no & $3.6 \%$ & 0.320 & $2.1 \%$ & 0.445 & $0.9 \%$ & 0.828 & $-0.3 \%$ & 0.908 \\
\hline AUT & yes & no & $-3.1 \%$ & 0.596 & $1.5 \%$ & 0.797 & $3.7 \%$ & 0.570 & $2.3 \%$ & $0.022 * *$ \\
\hline GER & no & yes & $-0.7 \%$ & 0.830 & $-1.2 \%$ & 0.453 & $-2.0 \%$ & 0.444 & $0.2 \%$ & 0.785 \\
\hline SUI & no & yes & $3.6 \%$ & 0.465 & $-4.7 \%$ & 0.097* & $-11.4 \%$ & $0.016^{* *}$ & $1.0 \%$ & 0.478 \\
\hline AUT & no & yes & $7.3 \%$ & 0.140 & $-6.0 \%$ & 0.276 & $-10.8 \%$ & 0.093 & $-0.4 \%$ & 0.698 \\
\hline GER & no & no & $-7.0 \%$ & $0.098 *$ & $-1.7 \%$ & 0.272 & $0.5 \%$ & 0.882 & $-1.1 \%$ & $0.049 * *$ \\
\hline SUI & no & no & $-5.7 \%$ & 0.120 & $-0.9 \%$ & 0.659 & $4.7 \%$ & 0.180 & $-0.1 \%$ & 0.944 \\
\hline AUT & no & no & $7.5 \%$ & 0.344 & $-1.8 \%$ & 0.843 & $-6.5 \%$ & 0.518 & $-1.1 \%$ & 0.300 \\
\hline \multicolumn{11}{|c|}{ Energy-related regulation } \\
\hline GER & yes & yes & $-7.4 \%$ & 0.068 & $-0.7 \%$ & 0.695 & $2.6 \%$ & 0.345 & $0.8 \%$ & 0.265 \\
\hline SUI & yes & yes & $4.6 \%$ & 0.454 & $-0.8 \%$ & 0.795 & $-6.2 \%$ & 0.315 & $1.2 \%$ & 0.350 \\
\hline AUT & yes & yes & $1.8 \%$ & 0.896 & $14.2 \%$ & 0.421 & $16.7 \%$ & 0.279 & $-0.6 \%$ & 0.436 \\
\hline GER & yes & no & $-3.0 \%$ & 0.525 & $-2.1 \%$ & 0.298 & $-2.6 \%$ & 0.477 & $-0.4 \%$ & 0.454 \\
\hline SUI & yes & no & $3.5 \%$ & 0.343 & $1.8 \%$ & 0.509 & $0.4 \%$ & 0.913 & $2.0 \%$ & 0.362 \\
\hline AUT & yes & no & $-4.9 \%$ & 0.498 & $1.1 \%$ & 0.862 & $4.5 \%$ & 0.546 & $-0.1 \%$ & 0.932 \\
\hline GER & no & yes & $5.5 \%$ & $0.029 * *$ & $0.1 \%$ & 0.930 & $-2.7 \%$ & 0.186 & $-0.2 \%$ & 0.704 \\
\hline SUI & no & yes & $6.3 \%$ & 0.148 & $-2.6 \%$ & 0.331 & $-9.5 \%$ & $0.022 * *$ & $-0.5 \%$ & 0.389 \\
\hline AUT & no & yes & $1.7 \%$ & 0.775 & $3.3 \%$ & 0.565 & $3.2 \%$ & 0.599 & $-0.8 \%$ & 0.484 \\
\hline GER & no & no & $-1.7 \%$ & 0.560 & $-0.3 \%$ & 0.862 & $0.5 \%$ & 0.846 & $-0.1 \%$ & 0.789 \\
\hline SUI & no & no & $-1.6 \%$ & 0.645 & $0.1 \%$ & 0.950 & $2.3 \%$ & 0.541 & $-0.9 \%$ & 0.329 \\
\hline AUT & no & no & $-1.9 \%$ & 0.832 & $-4.4 \%$ & 0.507 & $-4.6 \%$ & 0.531 & $0.4 \%$ & 0.768 \\
\hline \multicolumn{11}{|c|}{ Energy-related standards/voluntary agreements } \\
\hline GER & yes & yes & $0.4 \%$ & 0.921 & $1.4 \%$ & 0.496 & $2.4 \%$ & 0.441 & $-0.1 \%$ & 0.826 \\
\hline SUI & yes & yes & $10.6 \%$ & 0.178 & $-1.8 \%$ & 0.681 & $-11.7 \%$ & 0.249 & $0.5 \%$ & 0.584 \\
\hline AUT & yes & yes & $-8.9 \%$ & 0.522 & $4.5 \%$ & 0.652 & $11.9 \%$ & 0.143 & $0.5 \%$ & 0.740 \\
\hline GER & yes & no & $1.3 \%$ & 0.792 & $-1.8 \%$ & 0.441 & $-4.4 \%$ & 0.271 & $-0.9 \%$ & 0.108 \\
\hline SUI & yes & no & $-0.9 \%$ & 0.834 & $-0.3 \%$ & 0.915 & $0.1 \%$ & 0.974 & $-0.6 \%$ & 0.684 \\
\hline AUT & yes & no & $-0.5 \%$ & 0.944 & $2.7 \%$ & 0.701 & $3.9 \%$ & 0.630 & $0.5 \%$ & 0.519 \\
\hline GER & no & yes & $2.4 \%$ & 0.332 & $0.0 \%$ & 0.993 & $-1.3 \%$ & 0.500 & $0.0 \%$ & 0.983 \\
\hline SUI & no & yes & $5.3 \%$ & 0.205 & $1.2 \%$ & 0.703 & $-2.3 \%$ & 0.574 & $-0.5 \%$ & 0.567 \\
\hline AUT & no & yes & $6.0 \%$ & 0.302 & $-2.0 \%$ & 0.705 & $-5.9 \%$ & 0.302 & $-1.3 \%$ & 0.319 \\
\hline GER & no & no & $-5.0 \%$ & $0.084 *$ & $-1.1 \%$ & 0.381 & $0.4 \%$ & 0.863 & $-0.7 \%$ & 0.151 \\
\hline SUI & no & no & $-0.9 \%$ & 0.784 & $1.8 \%$ & 0.405 & $4.7 \%$ & 0.166 & $0.5 \%$ & 0.667 \\
\hline AUT & no & no & $-7.1 \%$ & 0.382 & $-3.1 \%$ & 0.634 & $0.2 \%$ & 0.982 & $0.0 \%$ & 0.967 \\
\hline \multicolumn{11}{|c|}{ Subsidies for energy technologies } \\
\hline GER & yes & yes & $3.1 \%$ & 0.441 & $2.4 \%$ & 0.336 & $2.8 \%$ & 0.430 & $0.2 \%$ & 0.808 \\
\hline SUI & yes & yes & $0.2 \%$ & 0.972 & $2.5 \%$ & 0.586 & $3.3 \%$ & 0.471 & $-0.6 \%$ & 0.721 \\
\hline AUT & yes & yes & $-15.2 \%$ & 0.227 & $-2.3 \%$ & 0.775 & $7.1 \%$ & 0.284 & $-0.7 \%$ & 0.364 \\
\hline GER & yes & no & $-0.6 \%$ & 0.902 & $-1.5 \%$ & 0.521 & $-3.3 \%$ & 0.385 & $-1.3 \%$ & $0.026^{* *}$ \\
\hline SUI & yes & no & $-7.6 \%$ & $0.078 *$ & $-1.0 \%$ & 0.748 & $5.9 \%$ & 0.257 & $0.3 \%$ & 0.890 \\
\hline AUT & yes & no & $2.2 \%$ & 0.820 & $-6.3 \%$ & 0.441 & $-9.0 \%$ & 0.346 & $-0.3 \%$ & 0.815 \\
\hline
\end{tabular}




\begin{tabular}{|c|c|c|c|c|c|c|}
\hline Country & $\begin{array}{l}\text { Energy } \\
\text { policy }\end{array}$ & $\begin{array}{l}\text { Techno- } \\
\text { logy } \\
\text { adoption }\end{array}$ & $\begin{array}{l}\text { Export activity in } \mathrm{t} \\
\text { Effect sign. }\end{array}$ & $\begin{array}{l}\text { Export share in } \mathrm{t} \\
\text { (all firms) } \\
\text { Effect sign. }\end{array}$ & $\begin{array}{l}\text { Export share in t } \\
\text { (exporters only) } \\
\text { Effect sign. }\end{array}$ & $\begin{array}{l}\text { Change in export } \\
\text { share betw. } \mathrm{t}-2 \text { and } \mathrm{t} \\
\text { Effect sign. }\end{array}$ \\
\hline GER & no & yes & $1.9 \% \quad 0.446$ & $0.4 \% \quad 0.758$ & $-0.3 \% \quad 0.867$ & $0.0 \% \quad 0.921$ \\
\hline SUI & no & yes & $4.7 \% \quad 0.206$ & $-0.2 \% \quad 0.924$ & $-4.0 \% \quad 0.294$ & $-0.6 \% \quad 0.466$ \\
\hline AUT & no & yes & $6.3 \% \quad 0.421$ & $-0.7 \% \quad 0.905$ & $-4.5 \% \quad 0.432$ & $-1.5 \% \quad 0.422$ \\
\hline GER & no & no & $-5.8 \% \quad 0.079 *$ & $-1.8 \% 0.151$ & $-0.8 \% \quad 0.765$ & $0.0 \% \quad 0.918$ \\
\hline SUI & no & no & $1.1 \% \quad 0.736$ & $-0.1 \% \quad 0.951$ & $-0.3 \% \quad 0.939$ & $-1.2 \% \quad 0.299$ \\
\hline AUT & no & no & $-6.7 \% \quad 0.331$ & $-2.8 \% \quad 0.610$ & $0.2 \% \quad 0.969$ & $-0.8 \% \quad 0.388$ \\
\hline \multicolumn{7}{|c|}{ Demand for energy-efficient products } \\
\hline GER & yes & yes & $1.6 \% \quad 0.706$ & $0.1 \% \quad 0.960$ & $-0.7 \% \quad 0.815$ & $0.4 \% \quad 0.410$ \\
\hline SUI & yes & yes & $-0.9 \% \quad 0.878$ & $-1.6 \% \quad 0.637$ & $-2.6 \% \quad 0.603$ & $0.3 \% \quad 0.709$ \\
\hline AUT & yes & yes & $-16.8 \% \quad 0.188$ & $1.1 \% \quad 0.922$ & $14.1 \% \quad 0.130$ & $-1.8 \% \quad 0.003 * * *$ \\
\hline GER & yes & no & $3.1 \% \quad 0.556$ & $-2.0 \% \quad 0.327$ & $-5.7 \% \quad 0.109$ & $-0.8 \% \quad 0.073 *$ \\
\hline SUI & yes & no & $-7.5 \% \quad 0.129$ & $2.4 \% \quad 0.561$ & $13.5 \% \quad 0.010^{* * *}$ & $3.8 \% \quad 0.355$ \\
\hline AUT & yes & no & $3.1 \% \quad 0.703$ & $-3.2 \% \quad 0.687$ & $-5.5 \% \quad 0.558$ & $0.6 \% \quad 0.537$ \\
\hline GER & no & yes & $2.2 \% \quad 0.377$ & $0.7 \% \quad 0.575$ & $0.0 \% \quad 0.990$ & $0.0 \% \quad 0.967$ \\
\hline SUI & no & yes & $0.084 *$ & $1.0 \% \quad 0.684$ & $-4.3 \% \quad 0.248$ & $0.5 \% \quad 0.640$ \\
\hline AUT & no & yes & $8.2 \% \quad 0.108$ & $\begin{array}{ll}5.8 \% & 0.288 \\
\end{array}$ & $2.2 \% \quad 0.704$ & $-0.5 \% \quad 0.640$ \\
\hline GER & no & no & $-4.5 \% \quad 0.105$ & $\begin{array}{ll}-0.4 \% & 0.761 \\
\end{array}$ & $1.5 \% \quad 0.543$ & $\begin{array}{ll}-0.2 \% & 0.616 \\
\end{array}$ \\
\hline SUI & no & no & $1.6 \% \quad 0.580$ & $0.2 \% \quad 0.905$ & $-0.3 \% \quad 0.926$ & $0.1 \% \quad 0.926$ \\
\hline AUT & no & no & $-4.6 \% \quad 0.379$ & $1.3 \% \quad 0.855$ & $4.2 \% \quad 0.568$ & $-0.9 \% \quad 0.469$ \\
\hline
\end{tabular}

$* * *, * *, *$ : significant at the $0.01,0.05,0.1$ level.

\section{Conclusions}

In this study, we tried to analyse the impacts of energy policies on international competitiveness of firms while considering a likely moderating role of energy technology adoption. Our study is based on cross-section data for three European countries with somewhat different approaches to energy policy: Germany, Switzerland and Austria. Employing a harmonised firm-level data set of more than 4,000 firms and using regression and matching techniques, we find very few significant impacts of energy policy on firm international competitiveness (using various export indicators as measures for competitiveness). Our empirical findings suggest that energy policy in the three countries, at least in the period covered by our study - 2012 to 2014 - had no relevant influence on firms' international market position. The only negative effect that appears at times stems from demand for energy-efficient products which seems to lead to some reorientation towards domestic markets. This result can also reflect a lack of regulatory framework abroad and hence a lower willingness to pay for environmentally friendlier produced products. For all other policy areas, including taxation, energy-related regulation and standards, and subsidies for energy technologies, we mostly find insignificant and rarely positively significant effects. Firms that introduced new energy technologies or that 
developed such technologies for the market report better export performance, indicating that investment in 'greener' energy technologies pays off.

These findings can be interpreted in different ways. If our empirical results are correct and robust, they imply that energy policy is not hurting international competitiveness. Likely negative impacts are either balanced by positive impacts of new technology adoption (see Arvanitis et al. 2016b) or the size of costs incurred by energy policy is too small to exert measurable effects. One has to keep in mind that the median of energy costs in total costs is about $1 \%$, and that the additional costs from energy taxes and energy-related regulation is a small fraction of total energy costs for the vast majority of firms. It is hence not surprising to find insignificant impacts on competitiveness. In addition, the three economies analysed in this paper have strong comparative advantages in producing and trading knowledge-intensive goods. For these goods, price competition is less relevant than quality competition based on innovativeness and customer-specific solutions.

Our results should be treated with caution, however, as they may be subject to several data limitations. First, our measure of energy policy is based on the assessment of firm managers rather than objective data (e.g. the actual amount of energy taxes paid). While the subjective measures enable a common scale for very different energy policy areas and also provide us with information on policy relevance for firms which may not be directly affected by certain policy measures, subjectivity may add substantial noise to our data. Furthermore, we only study energy policy impacts for a short period of time, 2012 to 2014. As energy policy in all three countries has been following a stable approach for more than a decade at least, it is likely that firms have adjusted to this policy, either by altering their processes or by shifting their product portfolio in a way that likely negative impacts of energy policy are avoided. In such a situation, the current level of policy relevance has little impacts on changes in competitiveness. Finally, we use crosssection data (with information on only two points in time) which impedes any analysis of longterm impacts or dynamic effects of policies. Future research should hence address these shortcomings of our study.

For energy policy in the three countries considered, our results imply that a more rigid approach as used in Germany (high energy taxes, strict and costly regulation) does not seem to imply a loss in competitiveness compared to neighbouring countries with similar economic structures and a somewhat (Austria) or significantly (Switzerland) less strict approach. This finding is however bound to the specific period of our study. Between 2012 and 2014, energy 
prices tended to fall, and additional costs of regulatory measures such as the CO2 emission trading system were low. In addition, some of the particularly costly measures of German energy policy, the EEG scheme to subsidising investment in renewable energy sources by an increase in electricity price mainly affected consumers whereas firms with huge energy demand and own electricity production facilities have largely been exempted from the cost burden. The higher costs for consumer stimulated demand for energy-efficient products, which in turn had an indirect effect on exports of firms adopting energy efficient technologies as domestic customers tend to show a higher willingness to pay for energy-efficiently produced products than customers abroad under a less strict energy policy regime.

\section{Acknowledgements:}

We thank Andrin Spescha, Maikel Pellens and Vanessa Behrens for their support in conducting this research. The research was generously sponsored through the National Research Programme (NRP) 71 "Managing Energy Consumption" of the Swiss National Science Foundation (SNF) (project no. 407140L_153901) and by the Austrian Science Fund (FWF). 


\section{References}

Ambec, S., Cohen, M.A., Elgie, S. \& Lanoie, P. (2013). The Porter hypothesis at 20: can environmental regulation enhance innovation and competitiveness? Review of Environmental Economics and Policy 7(1), 2-22.

Arnold, J.M. \& Hussinger, K. (2010). Exports versus FDI in German manufacturing: firm performance and participation in international markets. Review of International Economics 18(4), 595-606.

Arvanitis, S., Peneder, M., Rammer, C., Spescha, A., Stucki, T. \& Woerter, M. (2016a). Creation and Adoption of Energy-related Innovations - the Main Facts. KOF Studies No. 77, Zurich: KOF Swiss Economic Institute.

Arvanitis, S., Peneder, M., Rammer, C., Stucki, T. \& Woerter, M. (2016b). The Adoption of Green Energy Technologies: The Role of Policies in an International Comparison. KOF Working Papers 411, Zurich: Swiss Economic Institute.

Becker, S.O. \& Egger, P.H. (2013). Endogenous product versus process innovation and a firm's propensity to export. Empirical Economics 44, 329-354.

Beise-Zee, M. \& Rammer, C. (2006). Local User-Producer Interaction in Innovation and Export Performance of Firms. Small Business Economics 27(2-3), 207-222.

Beise, M. \& Rennings, K. (2005). Lead markets and regulation: a framework for analyzing the international diffusion of environmental innovations. Ecological Economics 52(1), 5-17.

Bertrand, M. \& Mullainathan, S. (2009). Do people mean what they say? Implications for subjective survey data. American Economic Review 91(2), 67-72.

Bleaney, M. \& Wakelin, K. (2002). Efficiency, innovation and exports. Oxford Bulletin of Economics and Statistics 64, 3-15.

BMWi (2012). Germany's New Energy Policy. Heading Towards 2050 with Secure, Affordable and Environmentally Sound Energy. Berlin: Federal Ministry of Economics and Technology.

BMWi (2016). Bundesbericht Energieforschung 2016. Forschung für die Energiewende. Berlin: Federal Ministry of Economics and Energy.

Büsgen, U. \& Dürrschmidt, W. (2009). The expansion of electricity generation from renewable energies in Germany: a review based on the Renewable Energy Sources Act Progress Report 2007 and the new German feed-in legislation. Energy Policy 37, 2536-2545.

Cantner, U., Graf, H., Herrmann, J. \& Kalthaus, M. (2016). Inventor networks in renewable energies: the influence of the policy mix in Germany, Research Policy 45, 1165-1184.

Cassiman, B., Golovko, E. \& Martínez-Ros, E. (2010). Innovation, exports and productivity. International Journal of Industrial Organization 28, 372-376.

Cohen, M.A. \& Tobb, A. (2015). The Impact of Environmental Regulation on Firm and Country Competitiveness: A Meta-Analysis of the Porter Hypothesis, mimeo, Vanderbilt University. 
Frondel, M., Ritter, N., Schmidt, C.M. \& Vance, C. (2010). Economic impacts from the promotion of renewable energy technologies: the German experience. Energy Policy 38, 4048-4056.

Gallagher, K.S., Grübler, A., Kuhl, L., Nemet, G. \& Wilson, C. (2012). The energy technology innovation system. Annual Review of Environment and Resources 37, 137-162.

Galvin, R. (2012). German Federal policy on thermal renovation of existing homes: a policy evaluation. Sustainable Cities and Society 4, 58-66.

Hong, G. (2010). Marginal mean weighting through stratification: adjustment for selection bias in multilevel data. Journal of Educational and Behavioral Statistics 35(5), 499-531.

Horbach, J., Rammer, C. \& Rennings, K. (2012). Determinants of eco-innovations by type of environmental impact - the role of regulatory push/pull, technology push and market pull. Ecological Economics 78, 112-122.

Horváthová, E. (2010). Does environmental performance affect financial performance? A metaanalysis. Ecological Economics 70, 52-59.

Iraldo, F., Testa, F. Melis, M. \& Frey, M. (2011). A literature review on the links between environmental regulation and competitiveness, Environmental Policy and Governance 21(3), $210-222$.

Jaffe, A.B. \& Palmer, K. (1997). Environmental regulation and innovation: a panel data study. Review of Economics and Statistics 79(4), 610-619.

Jaffe, A.B., Peterson, S.R., Portney, P.R. \& Stavins, R.N. (1995). Environmental regulation and the competitiveness of U.S. manufacturing: what does the evidence tell us? Journal of Economic Literature 33(1), 132-163.

Johnstone, N., Haščič, I., Poirier, J., Hemar, M. \& Michel, C. (2012). Environmental policy stringency and technological innovation: evidence from survey data and patent counts. Applied Economics 44(17), 2157-2170.

Jacobsson, S. \& Lauber, V. (2006). The politics and policy of energy system transformationexplaining the German diffusion of renewable energy technology. Energy Policy 34, 256276.

Kletzan-Slamanig, D. \& Köppl, A. (2016). Subventionen und Steuern mit Umweltrelevanz in den Bereichen Energie und Verkehr. Vienna: Austrian Institute of Economic Research (WIFO).

Köppl, A. \& Schratzenstaller, M. (2015). The Austrian Tax System - Status Quo. WIFO-Bulletin 20(5), 55-71.

Kronenberg, T., Kuckshinrichs, W. \& Hansen, P. (2012). Macroeconomic Effects of the German Government's Building Rehabilitation Program. Munich MPRA Paper No. 38815, Julich Research Centre.

Kuckshinrichs, W., Kronenberg, T. \& Hansen, P. (2010). The social return on investment in the energy efficiency of buildings in Germany. Energy Policy 38, 4317-4329. 
Lachenmaier, S. \& Wößmann, L. (2006). Does innovation cause exports? Evidence from exogenous innovation impulses and obstacles using German micro data. Oxford Economic Papers 58(2), 317-350.

Lanoie, P., Laurent-Lucchetti, J., Johnstone, N. \& Ambec, S. (2011). Environmental policy, innovation and performance: new insights on the Porter hypothesis. Journal of Economics \& Management Strategy 20(3), 803-842.

Lauber, V. \& Jacobsson, S. (2016). The politics and economics of constructing, contesting and restricting socio-political space for renewables - The German Renewable Energy Act. Environmental Innovation and Societal Transitions 18, 147-163.

Lehr, U., Nitsch, J., Kratzat, M., Lutz, C. \& Edler, D. (2009). Renewable energy and employment in Germany. Energy Policy 36(1), 108-117.

Lehr, U., Lutz, C. \& Edler, D. (2012). Green jobs? Economic impacts of renewable energy in Germany. Energy Policy 47, 358-364.

Lehr, U. \& Lutz, C. (2016). German Energiewende - quo vadis? In: Bardazzi, R., Pazienza, M.G. \& Tonini, A. (eds.). European Energy and Climate Security. Heidelberg: Springer International Publishing (Lecture Notes in Energy, vol. 31), 203-232.

Levinson, A. (2008). Pollution Haven Hypothesis (New Palgrave Dictionary of Economics, 2nd ed.). Basingstoke: Palgrave Macmillan.

Ley, M., Stucki, T. \& Woerter, M. (2016). The impact of energy prices on green innovation. The Energy Journal 37(1), 41-75.

Linn, J. (2008). Energy prices and the adoption of energy-saving technology. The Economic Journal 118, 1986-2012.

Lipp, J. (2007). Lessons for effective renewable electricity policy from Denmark, Germany and the United Kingdom. Energy Policy 35, 5481-5495.

Lutz, C., Lehr, U. \& Ulrich, P. (2014). Economic evaluation of climate protection measures in Germany. International Journal of Energy Economics and Policy 4(4), 693-705.

Millimet, D.L. \& Roy, J. (2015). Empirical tests of the pollution haven hypothesis when environmental regulation is endogenous. Journal of Applied Econometrics 31(4), 652-677.

Newell, R.G., Jaffe, A.B. \& Stavins, R.N. (1999). The induced innovation hypothesis and energy-saving technological change. Quarterly Journal of Economics 114(3), 941-975.

Nolden, C. (2013). Governing community energy-feed-in tariffs and the development of community wind energy schemes in the United Kingdom and Germany. Energy Policy 63, $543-552$.

Pellegrin, C. \& Woerter, M. (2016). Environmental Process Innovation and Production Cost Savings: An Analysis on Swiss Firm-level Panel Data, mimeo, Zürich/Lausanne.

Popp, D., Newell, R.G. \& Jaffe, A.B. (2010). Energy, the environment, and technological change. In: Hall, B.H. \& Rosenberg, N. (eds.). Handbook of the Economics of Innovation, vol. 2. Dordrecht: North-Holland, 873-937.

Porter, M.E. (1990). The Competitive Advantage of Nations. New York: Free Press. 
Porter, M.E. \& van der Linde, C. (1995). Toward a new conception of the environmentcompetitiveness relationship. The Journal of Economic Perspectives 9(4), 97-118.

Pregger, T., Nitsch, J. \& Naegler, T. (2013). Long-term scenarios and strategies for the deployment of renewable energies in Germany. Energy Policy 59, 350-360.

Rexhäuser, S. \& Rammer, C. (2014). Environmental innovations and firm profitability: unmasking the Porter ypothesis. Environmental and Resource Economics 57(1), 145-167.

Roper, S. \& Love, J.H. (2002). Innovation and export performance: evidence from UK and German manufacturing plants. Research Policy 32, 1087-1102.

Rosenow, J. (2013). The politics of the German CO2-Building Rehabilitation Programme. Energy Efficiency 6, 219-238.

Rubashkina, Y., Galeotti, M. \& Verdolini, E. (2015). Environmental regulation and competitiveness: Empirical evidence on the Porter hypothesis from European manufacturing sectors. Energy Policy 83, 288-300.

Schroeder, M., Ekins, P., Power, A., Zulauf, M. \& Lowe, R.J. (2011). The KFW Experience in the Reduction of Energy Use in and $\mathrm{CO} 2$ Emissions from Buildings: Operation, Impacts and Lessons for the UK. London: UCL Energy Institute, University College London and LSE Housing and Communities, London School of Economics.

Shadbegian, R. \& Wolverton, A. (2010). Location decisions of U.S. polluting plants: theory, empirical evidence, and consequences. International Review of Environmental and Resource Economics 1, 1-49.

Stucki, T. \& Woerter, M. (2016). Intra-firm diffusion of green energy technologies and the choice of policy instruments. Journal of Cleaner Production, forthcoming.

Veugelers, R. (2012). Which policy instruments to induce clean innovating? Research Policy 41(10), 1770-1778.

Wakelin, K. (1998). Innovation and export behaviour at the firm level. Research Policy 26, 829841.

Welfens, P.J.J. \& Lutz, C. (2012). Green ICT dynamics: key issues and findings for Germany. Mineral Economics 24, 155-163.

Weyant, J.P. (2011). Accelerating the development and diffusion of new energy technologies: beyond the "valley of death". Energy Economics 33, 674-682.

Xing, Y. \& Kolstad, C. (2002). Do lax environmental regulations attract foreign investment? Environmental and Resource Economics 21, 1-22.

Yu, H.J.J., Popiolek, N. \& Geoffron, P. (2016). Solar photovoltaic energy policy and globalization: a multiperspective approach with case studies of Germany, Japan, and China. Progress in Photovoltaics 24, 458-476. 


\section{Appendix}

Table 6: Variable definition, measurement and descriptive statistics

\begin{tabular}{|c|c|c|c|c|c|}
\hline Variable & Definition/measurement & Mean & Std. $d$. & Min & $\operatorname{Max}$ \\
\hline \multicolumn{6}{|l|}{ Dependent variable } \\
\hline Export share in $t$ & Percentage share of exports in total sales in $\mathrm{t}$ & 19.25 & 30.65 & 0.00 & 100.00 \\
\hline Export activity in $\mathrm{t}$ & Firm did sell products to customers abroad in $\mathrm{t}$ & 0.50 & 0.50 & 0 & 1 \\
\hline $\begin{array}{l}\text { Export share in } t \text { if export } \\
\text { activity }>0\end{array}$ & Share of exports in total sales & 38.27 & 33.76 & 0.02 & 100.00 \\
\hline Change in export share & (Export share in $\mathrm{t})$ - (export share in $\mathrm{t}-2)$ & 0.37 & 9.36 & -98.00 & 100.00 \\
\hline Change in export volume & $\ln (1+$ exports in $t$ in $€)-\ln (1+$ exports in $t-2$ in $€)$ & 0.04 & 2.39 & -17.93 & 19.94 \\
\hline \multicolumn{6}{|l|}{ Independent variables } \\
\hline Taxation & $\begin{array}{l}\text { Relevance of energy-related taxes during } \mathrm{t}-2 \text { to } \mathrm{t}(1 \text { : } \\
\text { somewhat or high, } 0 \text { : not) }\end{array}$ & 0.53 & 0.50 & 0 & 1 \\
\hline Regulation & $\begin{array}{l}\text { Relevance of energy-related regulations during } \mathrm{t}-2 \\
\text { to } \mathrm{t}(1 \text { : somewhat or high, } 0: \text { not) }\end{array}$ & 0.37 & 0.48 & 0 & 1 \\
\hline $\begin{array}{l}\text { Standards/voluntary } \\
\text { agreements }\end{array}$ & $\begin{array}{l}\text { Relevance of energy-related standards / voluntary } \\
\text { agreem. during t-2 to } \mathrm{t}(1 \text { : somewhat or high, } 0 \text { : not) }\end{array}$ & 0.31 & 0.46 & 0 & 1 \\
\hline Public subsidies & $\begin{array}{l}\text { Relevance of energy-related public subsidies during } \\
\mathrm{t}-2 \text { to } \mathrm{t}(1 \text { : somewhat or high, } 0: \text { not) }\end{array}$ & 0.34 & 0.47 & 0 & 1 \\
\hline Demand & $\begin{array}{l}\text { Relevance of demand for energy efficient products } \\
\text { during t-2 to } t \text { ( } 1 \text { : somewhat or high, } 0: \text { not) }\end{array}$ & 0.26 & 0.44 & 0 & 1 \\
\hline $\begin{array}{l}\text { Adoption of energy } \\
\text { technology }\end{array}$ & $\begin{array}{l}\text { Firm introduced new energy technologies during } t-2 \\
\text { to } t\end{array}$ & 0.47 & 0.50 & 0 & 1 \\
\hline $\begin{array}{l}\text { Key motive: efficiency } \\
\text { gains }\end{array}$ & $\begin{array}{l}\text { Increasing energy efficiency was a key motive for } \\
\text { energy technology adoption }\end{array}$ & 0.25 & 0.43 & 0 & 1 \\
\hline Key motive: others & $\begin{array}{l}\text { Increasing energy efficiency was not a key motive } \\
\text { for energy technology adoption }\end{array}$ & 0.22 & 0.41 & 0 & 1 \\
\hline Efficiency gains achieved & $\begin{array}{l}\text { Adoption of new energy technologies led to an } \\
\text { increase in energy efficiency }\end{array}$ & 0.29 & 0.45 & 0 & 1 \\
\hline $\begin{array}{l}\text { Development of energy } \\
\text { technology }\end{array}$ & $\begin{array}{l}\text { Firm developed new energy technologies during } \mathrm{t}-2 \\
\text { and } \mathrm{t} \text { for sale on the market }\end{array}$ & 0.07 & 0.26 & 0 & 1 \\
\hline Export share in $\mathrm{t}-2$ & Percentage share of exports in total sales in $\mathrm{t}-2$ & 14.29 & 27.34 & 0.00 & 100.00 \\
\hline Export activity in $\mathrm{t}-2$ & Firm did sell products to customers abroad in $\mathrm{t}-2$ & 0.41 & 0.49 & 0 & 1 \\
\hline Energy intensity in $\mathrm{t}-2$ & Share of energy expenditure in total sales in $\mathrm{t}-2$ & 2.22 & 6.39 & 0.00 & 280.00 \\
\hline $\begin{array}{l}\text { Energy source: own } \\
\text { renewables }\end{array}$ & $\begin{array}{l}\text { Firm used electric energy generated from own } \\
\text { renewable sources during } \mathrm{t}-2 \text { and } \mathrm{t}\end{array}$ & 0.03 & 0.17 & 0 & 1 \\
\hline Energy source: oil & Firm used oil as energy source during $\mathrm{t}-2$ and $\mathrm{t}$ & 0.05 & 0.23 & 0 & 1 \\
\hline $\begin{array}{l}\text { Energy source: natural } \\
\text { gas }\end{array}$ & $\begin{array}{l}\text { Firm used natural gas as energy source during } t-2 \\
\text { and } t\end{array}$ & 0.09 & 0.28 & 0 & 1 \\
\hline Other product innovation & $\begin{array}{l}\text { Firm introduced product innovations during } \mathrm{t}-2 \text { and } \\
\mathrm{t} \text { (other than development of energy technologies) }\end{array}$ & 0.38 & 0.49 & 0 & 1 \\
\hline Other process innovation & $\begin{array}{l}\text { Firm introduced process innovations during } \mathrm{t}-2 \text { and } \\
\mathrm{t} \text { (other than new energy technologies) }\end{array}$ & 0.13 & 0.34 & 0 & 1 \\
\hline Size & Number of employees (full-time equivalents) in $t, \ln$ & 3.43 & 1.01 & 0.00 & 6.24 \\
\hline Age & Firm age in years in $t, \ln$ & 3.75 & 1.62 & 0.00 & 11.63 \\
\hline Foreign owned & Firm is owned by a foreign company & 0.10 & 0.30 & 0 & 1 \\
\hline Domestic group & Firm is part of a domestic enterprise group & 0.22 & 0.42 & 0 & 1 \\
\hline Unit labour cost & Relation between labour cost and value added in & 0.43 & 0.53 & 0.00 & 15.00 \\
\hline Material share & Share of material and service input in total sales in $t$ & 0.31 & 0.25 & 0.00 & 1.00 \\
\hline $\begin{array}{l}\text { Relative labour } \\
\text { productivity } \mathrm{t}-2\end{array}$ & $\begin{array}{l}\text { Value added per FTE employee in } \mathrm{t}-2 \text {, divided by } \\
\text { labour productivity in a firms } 2 \text {-digit industry, } \ln \end{array}$ & 0.61 & 1.80 & -7.89 & 63.58 \\
\hline Switzerland & Firm located in Switzerland & 0.08 & 0.28 & 0 & 1 \\
\hline Austria & Firm located in Austria & 0.40 & 0.49 & 0 & 1 \\
\hline
\end{tabular}


Table 7: Impact of energy policy relevance and energy technology adoption on export performance of firms: estimation results of probit models on the probability to export

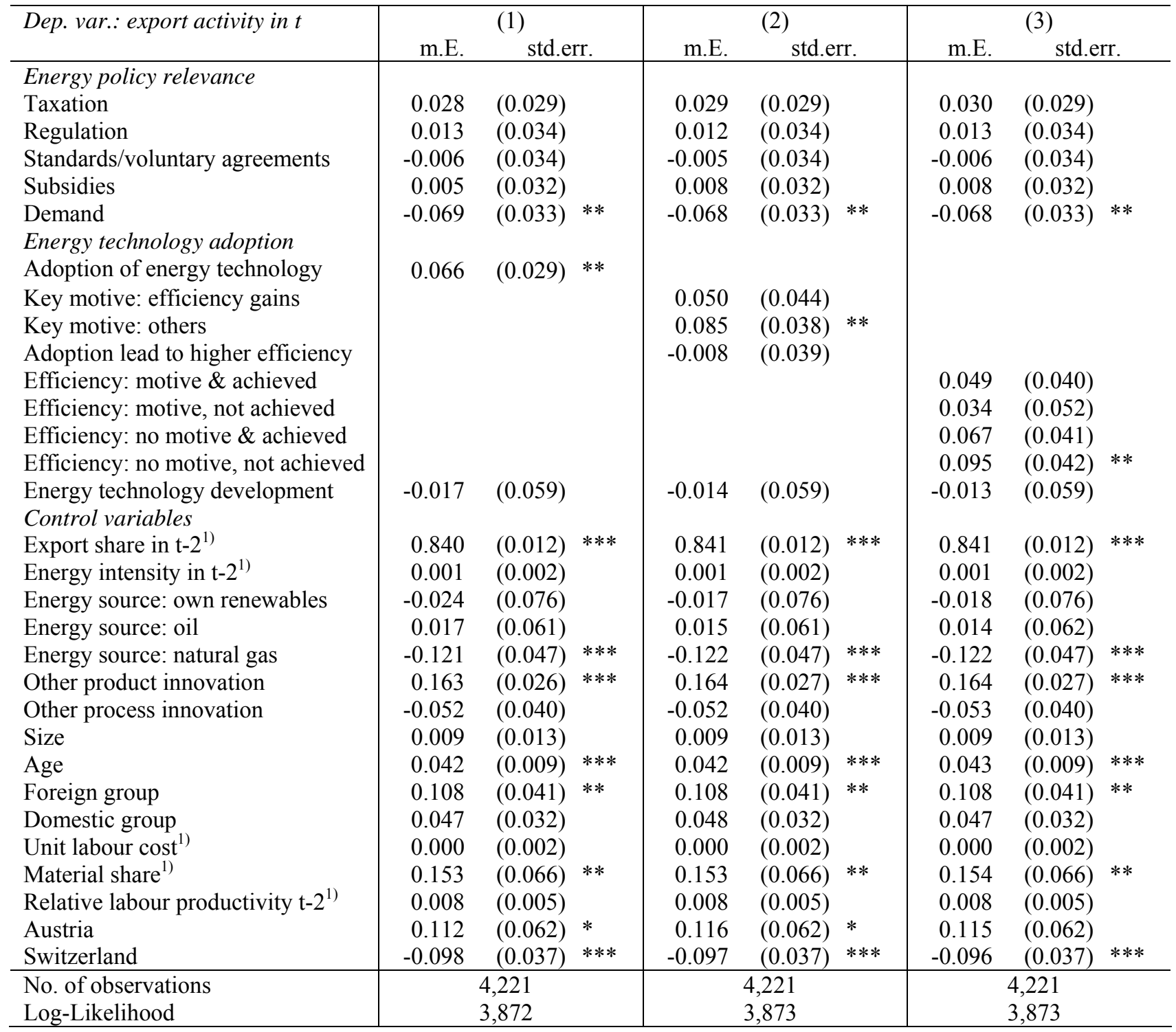

$* * *, * *, *$ : significant at the $0.01,0.05,0.1$ level.

Each model includes 25 industry dummies which are jointly significant.

1) Missing values are set to 0 and dummy variables indicating missing observations have been included. 
Table 8: Impact of energy policy relevance and energy technology adoption on the export performance: estimation results of OLS models on the export share of exporting firms

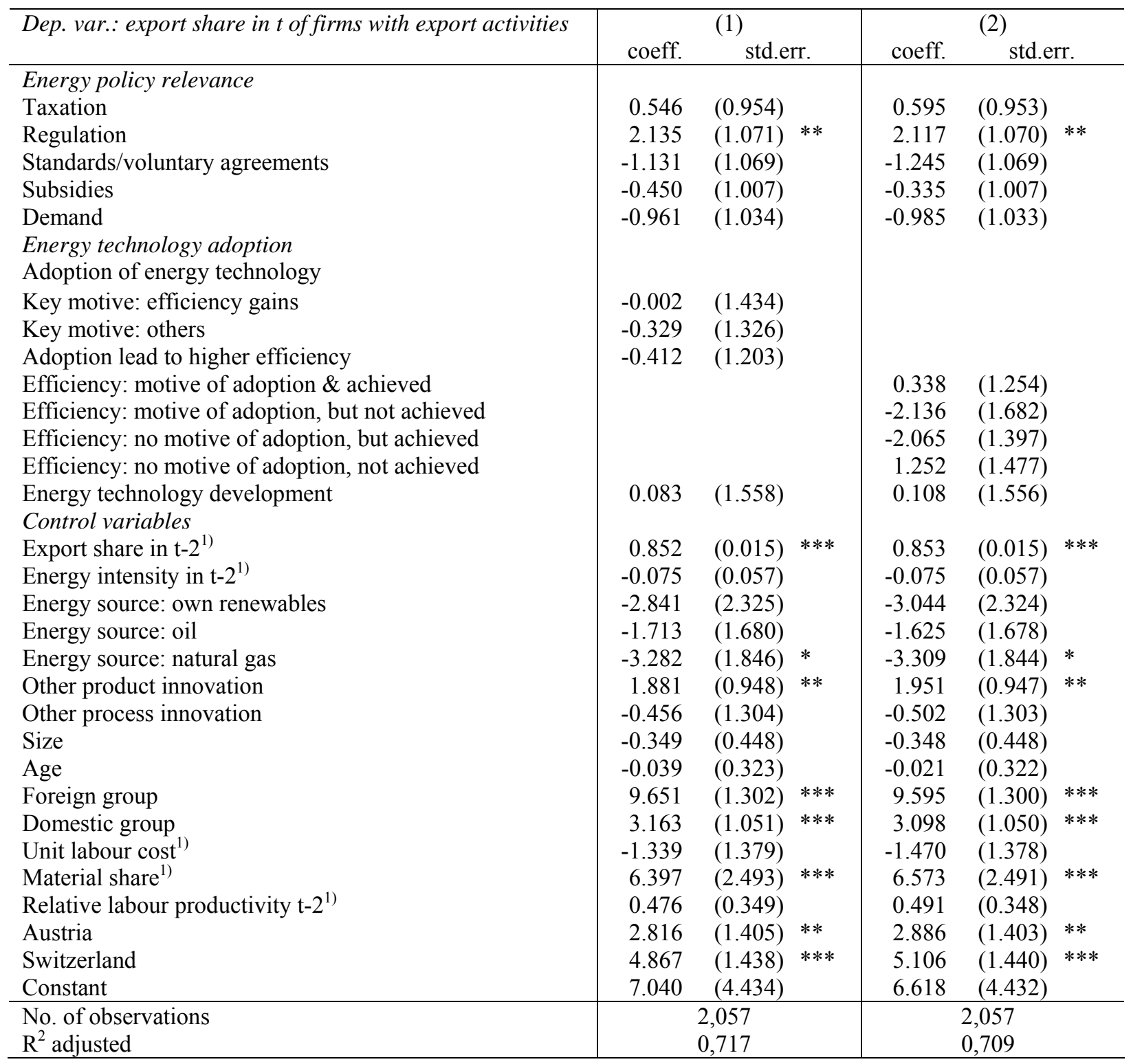

$* * *, * *, *$ : significant at the $0.01,0.05,0.1$ level.

Each model includes 25 industry dummies which are jointly significant.

1) Missing values are set to 0 and dummy variables indicating missing observations have been included. 
Table 9: Impact of energy policy relevance and energy technology adoption on change in export performance of exporting firms: estimation results of OLS models

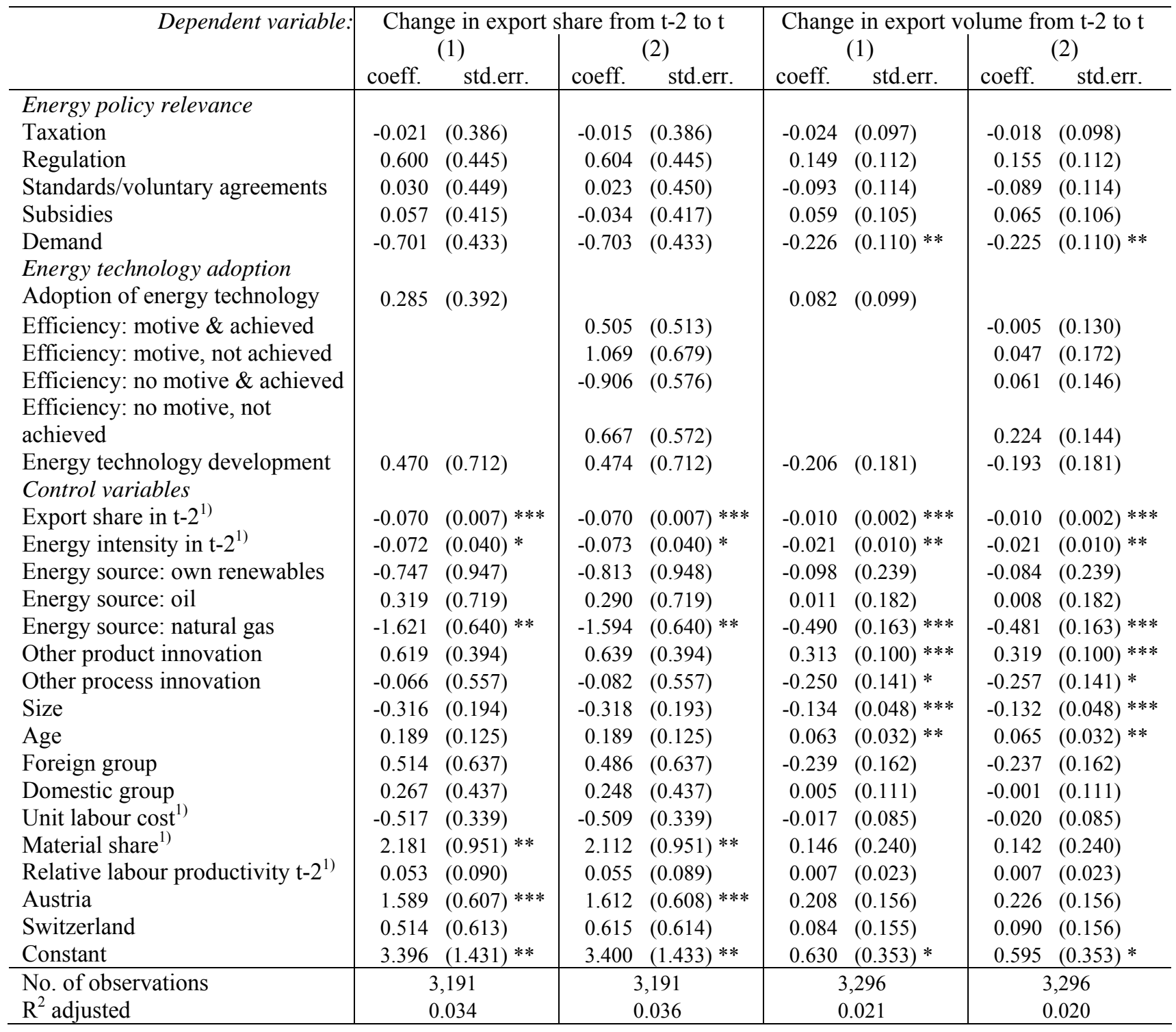

$* * *, * *, *$ : significant at the $0.01,0.05,0.1$ level.

Each model includes 25 industry dummies which are jointly significant.

1) Missing values are set to 0 and dummy variables indicating missing observations have been included. 
Table 10: Impact of combinations of energy policy relevance and energy technology adoption patterns on export performance of firms: estimation results of probit and OLS models

\begin{tabular}{|c|c|c|}
\hline Dependent variable: & $\begin{array}{l}\text { export activity in } \mathrm{t} \\
\text { (probit) } \\
\text { m.E. std.err. }\end{array}$ & $\begin{array}{l}\text { export share for ex- } \\
\text { port activity }>0 \text { (OLS) } \\
\text { coeff. std.err. }\end{array}$ \\
\hline \multicolumn{3}{|l|}{ Energy policy \& adoption motives / impacts } \\
\hline Taxation \& motive efficiency + increase in efficiency & $0.049(0.065)$ & $0.208(1.777)$ \\
\hline Regulation \& motive efficiency + increase in efficiency & $-0.119(0.075)$ & $4.818(2.006) * *$ \\
\hline Stand./vol. agr. \& motive efficiency + increase in efficiency & $0.038(0.071)$ & $-0.299(1.944)$ \\
\hline Subsidies \& motive efficiency + increase in efficiency & $0.109(0.059) *$ & $-1.991(1.855)$ \\
\hline Demand $\&$ motive efficiency + increase in efficiency & $-0.073(0.071)$ & $-1.121(1.913)$ \\
\hline Taxation \& motive efficiency + no increase in efficiency & $0.010(0.097)$ & $0.492(3.004)$ \\
\hline Regulation \& motive efficiency + no increase in efficiency & $0.017(0.119)$ & $-1.817(3.821)$ \\
\hline Stand./vol. agr. \& motive efficiency + no increase in efficiency & $-0.161(0.115)$ & $5.288(3.369)$ \\
\hline Subsidies $\&$ motive efficiency + no increase in efficiency & $0.082(0.090)$ & $-1.057(2.880)$ \\
\hline Demand \& motive efficiency + no increase in efficiency & $-0.032(0.111)$ & $-4.294(3.461)$ \\
\hline Taxation $\&$ no motive efficiency + increase in efficiency & $0.156(0.064) * *$ & $0.542(2.276)$ \\
\hline Regulation \& no mot. efficiency + increase in efficiency & $-0.169(0.092) *$ & $-0.723(2.913)$ \\
\hline Stand./vol. agr. \& no motive efficiency + increase in efficiency & $-0.031(0.090)$ & $1.562(2.772)$ \\
\hline Subsidies \& no motive efficiency + increase in efficiency & $0.120(0.077)$ & $0.242(2.761)$ \\
\hline Demand \& no motive efficiency + increase in efficiency & $-0.067(0.084)$ & $-2.426(2.579)$ \\
\hline Taxation \& no motive efficiency, no increase in efficiency & $0.101(0.076)$ & $-1.210(2.533)$ \\
\hline Regulation \& no motive efficiency, no increase in efficiency & $0.026(0.107)$ & $5.617(3.360) *$ \\
\hline Stand./vol. agr. \& no motive efficiency, no increase in efficiency & $-0.058(0.112)$ & $-2.426(3.284)$ \\
\hline Subsidies \& no motive efficiency, no increase in efficiency & $0.051(0.089)$ & $1.001(2.848)$ \\
\hline Demand \& no motive efficiency, no increase in efficiency & $-0.066(0.097)$ & $0.388(2.781)$ \\
\hline Taxation \& no adoption & $-0.015(0.038)$ & $1.294(1.276)$ \\
\hline Regulation \& no adoption & $0.109(0.045) * *$ & $1.803(1.647)$ \\
\hline Stand./voluntary agreements \& no adoption & $0.030(0.051)$ & $-4.882(1.852) * * *$ \\
\hline Subsidies \& no adoption & $-0.112(0.050) * *$ & $0.780(1.712)$ \\
\hline Demand \& no adoption & $-0.062(0.049)$ & $0.306(1.715)$ \\
\hline $\begin{array}{l}\text { Energy technology development } \\
\text { Control variables }\end{array}$ & $-0.006(0.060)$ & $0.070(1.559)$ \\
\hline Export share in $\mathrm{t}-2^{1)}$ & $0.847(0.011) * * *$ & $0.853(0.016) * * *$ \\
\hline Energy intensity in $\mathrm{t}-2^{1)}$ & $0.001(0.002)$ & $-0.073(0.057)$ \\
\hline Energy source: own renewables & $-0.025(0.077)$ & $-2.900(2.335)$ \\
\hline Energy source: oil & $0.021(0.062)$ & $-1.590(1.690)$ \\
\hline Energy source: natural gas & $-0.123(0.047) * * *$ & $-3.303(1.853) *$ \\
\hline Other product innovation & $0.172(0.027) * * *$ & $1.681(0.950) *$ \\
\hline Other process innovation & $-0.075(0.039) *$ & $-0.089(1.250)$ \\
\hline Size & $0.009(0.013)$ & $-0.409(0.450)$ \\
\hline Age & $0.046(0.009) * * *$ & $-0.087(0.322)$ \\
\hline Foreign group & $0.103(0.041) * *$ & $9.540(1.308) * * *$ \\
\hline Domestic group & $0.046(0.032)$ & $3.179(1.055) * * *$ \\
\hline Unit labour cost $t^{1)}$ & $0.000(0.002)$ & $-1.398(1.384)$ \\
\hline Material share $^{1)}$ & $0.155(0.067) * *$ & $6.642(2.508) * * *$ \\
\hline Relative labour productivity $t-2^{1)}$ & $0.008(0.006)$ & $0.489(0.350)$ \\
\hline Austria & $0.094(0.064)$ & $3.229(1.415) * *$ \\
\hline Switzerland & $-0.100(0.037) * * *$ & $4.889(1.441) * * *$ \\
\hline Constant & & $7.023(4.456)$ \\
\hline No. of observations & 4,221 & 2,057 \\
\hline $\mathrm{R}^{2}$ adjusted & & 0.709 \\
\hline Log-Likelihood & 3,894 & \\
\hline
\end{tabular}

***, **, *: significant at the $0.01,0.05,0.1$ level.

Each model includes 25 industry dummies which are jointly significant.

1) Missing values are set to 0 and dummy variables indicating missing observations have been included. 
Table 11: Impact of combinations of energy policy relevance and energy technology adoption patterns on change in export performance of firms: estimation results of OLS models

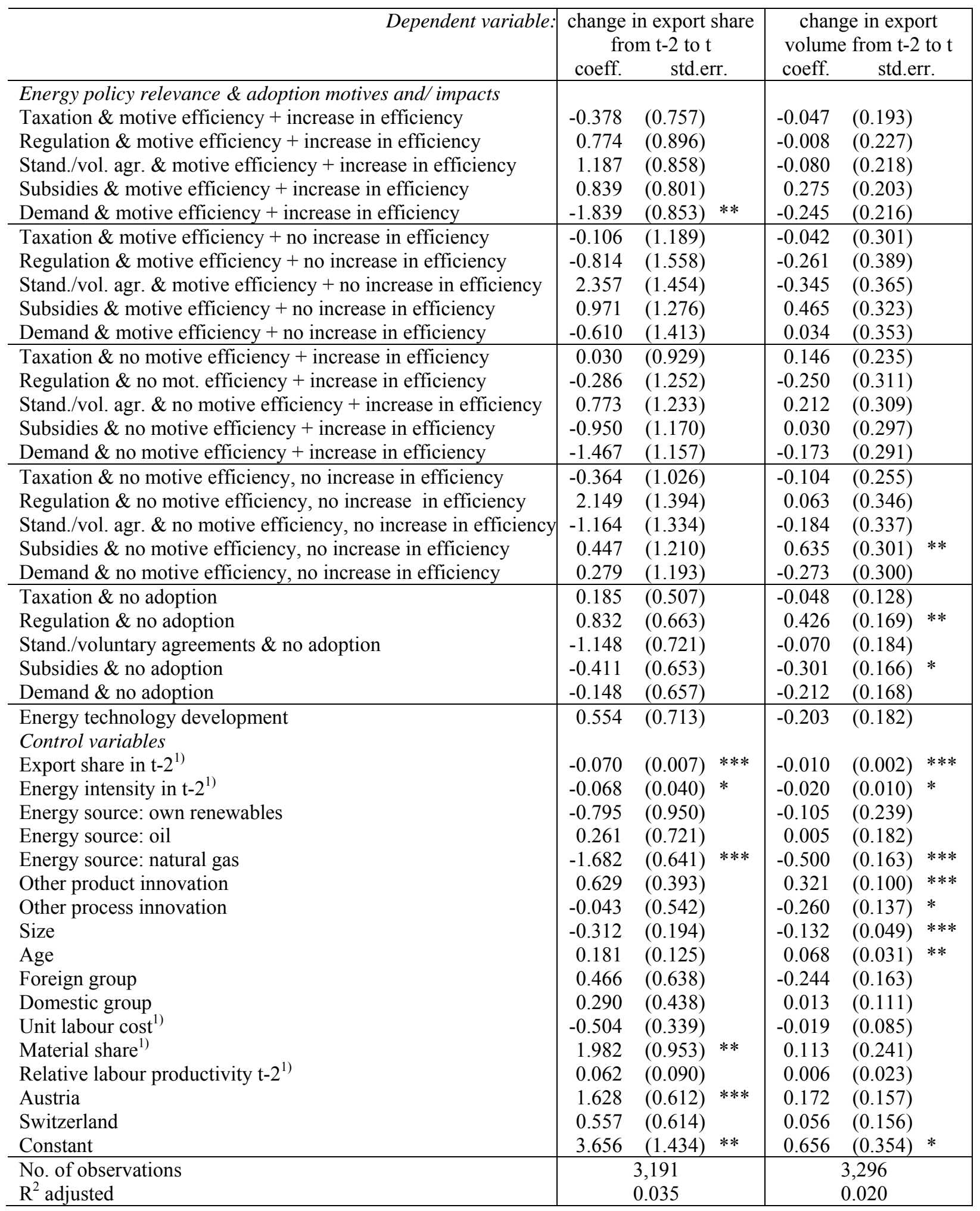

$* * *, * *, *$ : significant at the $0.01,0.05,0.1$ level.

Each model includes 25 industry dummies which are jointly significant.

1) Missing values are set to 0 and dummy variables indicating missing observations have been included. 
Table 12: Impact of combinations of energy policy relevance and energy technology adoption patterns on export performance of firms: estimation results for an alternative measurement of policy relevance (considering 'highly relevant' policies only)

\begin{tabular}{|c|c|c|c|c|c|c|c|c|c|c|c|c|}
\hline \multirow{7}{*}{$\begin{array}{l}\text { Energy policy relevance \& } \\
\text { adoption motives / impacts } \\
\text { Taxation \& motive efficiency + increase in efficiency } \\
\text { Regulation \& motive efficiency + increase in efficiency } \\
\text { Standards/voluntary agreem. \& motive efficiency }+ \text { increase in efficiency } \\
\text { Subsidies \& motive efficiency + increase in efficiency } \\
\text { Demand \& motive efficiency + increase in efficiency }\end{array}$} & \multicolumn{3}{|c|}{$\begin{array}{l}\text { export share in } \mathrm{t} \\
\text { (tobit) }\end{array}$} & \multicolumn{3}{|c|}{$\begin{array}{l}\text { export activity in } \mathrm{t} \\
\text { (probit) }\end{array}$} & \multicolumn{3}{|c|}{$\begin{array}{l}\text { export share for export } \\
\text { activity }>0 \text { (OLS) }\end{array}$} & \multicolumn{3}{|c|}{$\begin{array}{l}\text { change in export share } \\
\text { betw. } t-2 \text { and } t \text { (OLS) }\end{array}$} \\
\hline & coeff. & std.err. & & coeff. & std.err & & coeff. & std.err & & coeff. & & \\
\hline & 1.17 & $(2.352)$ & & 0.09 & $(0.073)$ & & 0.78 & $(2.059)$ & & 1.47 & $(0.895)$ & \\
\hline & 3.91 & $(2.682)$ & & -0.02 & $(0.089)$ & & 5.46 & (2.304) & $* *$ & -0.43 & $(1.090)$ & \\
\hline & 2.43 & (2.946) & & -0.04 & $(0.100)$ & & -0.12 & $(2.556)$ & & 2.38 & (1.183) & $* *$ \\
\hline & 0.74 & $(2.532)$ & & 0.09 & $(0.076)$ & & -2.12 & (2.194) & & -0.51 & $(1.010)$ & \\
\hline & -1.99 & $(3.321)$ & & -0.11 & $(0.104)$ & & 2.25 & $(3.087)$ & & -0.63 & $(1.260)$ & \\
\hline Taxation \& motive efficiency + no increase in efficiency & -2.95 & $(4.413)$ & & -0.09 & $(0.132)$ & & -0.94 & $(4.098)$ & & 0.78 & $(1.598)$ & \\
\hline Regulation \& motive efficiency + no increase in efficiency & 3.97 & $(5.169)$ & & 0.15 & $(0.137)$ & & 0.73 & $(4.638)$ & & -0.32 & $(2.093)$ & \\
\hline Standards/voluntary agr. \& motive efficiency + no increase in efficiency & 0.35 & $(4.586)$ & & -0.14 & $(0.152)$ & & 2.35 & $(4.069)$ & & 2.17 & $(1.849)$ & \\
\hline Subsidies $\&$ motive efficiency + no increase in efficiency & -2.93 & $(4.004)$ & & -0.07 & $(0.120)$ & & -4.14 & $(3.492)$ & & -0.51 & $(1.608)$ & \\
\hline Demand \& motive efficiency + no increase in efficiency & 2.79 & $(4.296)$ & & 0.02 & $(0.118)$ & & 2.07 & $(3.840)$ & & 1.24 & $(1.746)$ & \\
\hline Taxation \& no motive efficiency + increase in efficiency & 3.88 & $(3.413)$ & & 0.25 & $(0.075)$ & $* *$ & 1.04 & $(2.919)$ & & -0.22 & $(1.298)$ & \\
\hline Regulation \& no mot. efficiency + increase in efficiency & -4.93 & $(4.349)$ & & -0.12 & $(0.123)$ & & -4.65 & $(3.889)$ & & -0.02 & $(1.867)$ & \\
\hline Standards/voluntary agr. \& no motive efficiency + increase in efficiency & -9.44 & $(4.905)$ & $*$ & -0.09 & $(0.142)$ & & -5.24 & $(4.478)$ & & 0.30 & $(1.926)$ & \\
\hline Subsidies \& no motive efficiency + increase in efficiency & 5.68 & $(4.281)$ & & 0.13 & $(0.107)$ & & 5.64 & $(3.813)$ & & 0.41 & $(1.704)$ & \\
\hline Demand \& no motive efficiency + increase in efficiency & -2.70 & $(5.476)$ & & 0.05 & $(0.147)$ & & -1.34 & $(5.000)$ & & -0.86 & $(2.195)$ & \\
\hline Taxation \& no motive efficiency, no increase in efficiency & 9.30 & $(3.684)$ & ** & 0.25 & $(0.077)$ & ** & 3.95 & $(3.258)$ & & 0.32 & $(1.363)$ & \\
\hline Regulation \& no motive efficiency, no increase in efficiency & 5.86 & $(5.793)$ & & -0.12 & $(0.176)$ & & 11.72 & $(5.330)$ & & -0.11 & $(2.313)$ & \\
\hline Standards/voluntary agr. \& no motive efficiency, no increase in efficiency & -5.18 & $(5.826)$ & & -0.08 & $(0.198)$ & & -5.28 & $(5.038)$ & & 0.46 & $(2.292)$ & \\
\hline Subsidies \& no motive efficiency, no increase in efficiency & -4.32 & $(4.600)$ & & -0.13 & $(0.143)$ & & -2.84 & $(4.265)$ & & -0.97 & $(1.652)$ & \\
\hline Demand \& no motive efficiency, no increase in efficiency & -2.93 & $(4.910)$ & & -0.11 & $(0.144)$ & & -3.15 & $(4.506)$ & & 1.00 & $(1.926)$ & \\
\hline Taxation \& no adoption & 1.84 & $(2.152)$ & & -0.02 & $(0.060)$ & & 0.81 & $(2.077)$ & & -0.58 & $(0.775)$ & \\
\hline Regulation \& no adoption & 1.75 & $(3.141)$ & & 0.11 & $(0.076)$ & & 1.19 & $(2.999)$ & & 2.84 & $(1.231)$ & $* *$ \\
\hline Standards/voluntary agreements \& no adoption & -2.35 & $(3.739)$ & & -0.13 & $(0.104)$ & & -0.05 & $(3.674)$ & & -0.72 & $(1.353)$ & \\
\hline Subsidies \& no adoption & -1.30 & $(3.278)$ & & -0.03 & $(0.091)$ & & -3.09 & $(3.239)$ & & -2.05 & $(1.158)$ & $*$ \\
\hline Demand \& no adoption & -4.53 & $(3.715)$ & & -0.11 & $(0.107)$ & & -0.53 & $(3.717)$ & & 0.29 & $(1.232)$ & \\
\hline Energy technology development & 4.25 & $(1.791)$ & ** & -0.01 & $(0.060)$ & & -0.08 & $(1.561)$ & & 0.34 & $(0.712)$ & \\
\hline
\end{tabular}




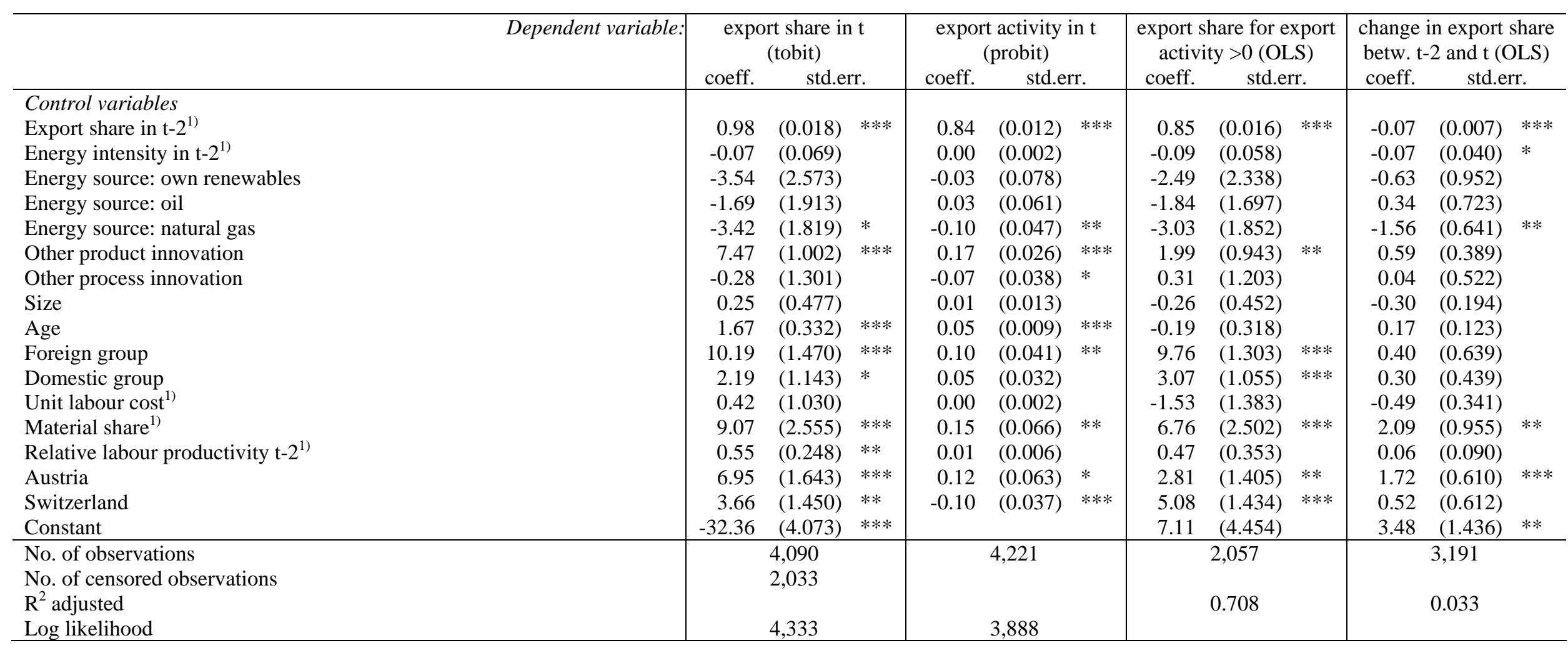

***, **, *: significant at the 0.01, 0.05, 0.1 level.

Each model includes 25 industry dummies which are jointly significant.

1) Missing values are set to 0 and dummy variables indicating missing observations have been included. 
Table 13: Matching results on export performance by combinations of energy policy relevance and key motive of energy technology adoption, by country

\begin{tabular}{|c|c|c|c|c|c|c|c|c|c|c|}
\hline \multirow{3}{*}{\multicolumn{2}{|c|}{$\begin{array}{cc}\text { Country } & \begin{array}{l}\text { Energy } \\
\text { policy }\end{array} \\
\text { Energy taxes } \\
\end{array}$}} & \multirow[t]{2}{*}{$\begin{array}{l}\text { Effi- } \\
\text { ciency } \\
\text { motive } \\
\end{array}$} & \multicolumn{2}{|c|}{$\begin{array}{l}\text { Export activity in } \mathrm{t} \\
\text { Effect sign. }\end{array}$} & \multicolumn{2}{|c|}{$\begin{array}{l}\text { Export share in } \mathrm{t} \\
\text { (all firms) } \\
\text { Effect sign. }\end{array}$} & \multicolumn{2}{|c|}{$\begin{array}{l}\text { Export share in } \mathrm{t} \\
\text { (exporters only) } \\
\text { Effect sign. }\end{array}$} & \multicolumn{2}{|c|}{$\begin{array}{l}\text { Change in export } \\
\text { share betw. } \mathrm{t}-2 \text { and } \mathrm{t} \\
\text { Effect sign. }\end{array}$} \\
\hline & & & & & & & & & & \\
\hline & & yes & $-3.0 \%$ & 0.573 & $-0.6 \%$ & 0.737 & $1.8 \%$ & 0.503 & $0.4 \%$ & 0.314 \\
\hline SUI & yes & yes & $-7.8 \%$ & 0.292 & $-3.0 \%$ & 0.495 & $0.7 \%$ & 0.890 & $1.1 \%$ & 0.174 \\
\hline AUT & yes & yes & $0.2 \%$ & 0.967 & $0.3 \%$ & 0.965 & $0.2 \%$ & 0.976 & $-0.7 \%$ & 0.584 \\
\hline GER & yes & no & $0.4 \%$ & 0.940 & $0.4 \%$ & 0.891 & $0.3 \%$ & 0.946 & $-0.4 \%$ & 0.463 \\
\hline SUI & yes & no & $5.6 \%$ & 0.325 & $3.6 \%$ & 0.403 & $1.4 \%$ & 0.801 & $1.2 \%$ & 0.622 \\
\hline AUT & yes & no & $2.7 \%$ & 0.722 & $3.7 \%$ & 0.645 & $2.8 \%$ & 0.733 & $0.4 \%$ & 0.824 \\
\hline GER & no & yes & $3.9 \%$ & 0.498 & $1.0 \%$ & 0.775 & $-0.5 \%$ & 0.930 & $2.0 \%$ & 0.412 \\
\hline SUI & no & yes & $-4.3 \%$ & 0.683 & $-9.0 \%$ & $0.015^{* *}$ & $-6.1 \%$ & 0.206 & $0.2 \%$ & 0.839 \\
\hline AUT & no & yes & $-7.5 \%$ & 0.463 & $-8.7 \%$ & 0.243 & $-6.7 \%$ & 0.451 & $0.5 \%$ & 0.662 \\
\hline GER & no & no & $-6.2 \%$ & 0.161 & $-2.6 \%$ & 0.196 & $-1.4 \%$ & 0.696 & $0.0 \%$ & 0.960 \\
\hline SUI & no & no & $-0.6 \%$ & 0.938 & $3.2 \%$ & 0.674 & $7.0 \%$ & 0.431 & $-0.9 \%$ & 0.506 \\
\hline AUT & no & no & $11.1 \%$ & $0.050^{* *}$ & $-0.7 \%$ & 0.924 & $-6.9 \%$ & 0.350 & $0.2 \%$ & 0.897 \\
\hline \multicolumn{11}{|c|}{ Energy-related regulation } \\
\hline GER & yes & yes & $-6.0 \%$ & 0.291 & $1.7 \%$ & 0.598 & $6.5 \%$ & 0.192 & $3.0 \%$ & 0.278 \\
\hline SUI & yes & yes & $-0.4 \%$ & 0.970 & $-2.8 \%$ & 0.550 & $-5.8 \%$ & 0.521 & $1.3 \%$ & $0.093 *$ \\
\hline AUT & yes & yes & $-17.8 \%$ & 0.175 & $1.4 \%$ & 0.902 & $14.4 \%$ & 0.147 & $-0.4 \%$ & 0.650 \\
\hline GER & yes & no & $-4.5 \%$ & 0.402 & $-1.4 \%$ & 0.522 & $-0.4 \%$ & 0.904 & $0.1 \%$ & 0.850 \\
\hline SUI & yes & no & $5.7 \%$ & 0.471 & $2.6 \%$ & 0.618 & $-0.4 \%$ & 0.959 & $4.9 \%$ & 0.396 \\
\hline AUT & yes & no & $20.1 \%$ & $0.000 * * *$ & $8.1 \%$ & 0.395 & $-1.6 \%$ & 0.866 & $-2.4 \%$ & $0.051^{*}$ \\
\hline GER & no & yes & $4.9 \%$ & 0.192 & $1.8 \%$ & 0.410 & $0.5 \%$ & 0.869 & $0.6 \%$ & 0.231 \\
\hline SUI & no & yes & $-4.5 \%$ & 0.497 & $-7.9 \%$ & $0.015 * *$ & $-8.9 \%$ & $0.049 * *$ & $-0.9 \%$ & 0.268 \\
\hline AUT & no & yes & $-1.2 \%$ & 0.854 & $-0.7 \%$ & 0.910 & $-0.2 \%$ & 0.978 & $-0.4 \%$ & 0.741 \\
\hline GER & no & no & $2.1 \%$ & 0.529 & $-1.2 \%$ & 0.437 & $-3.2 \%$ & 0.199 & $-0.2 \%$ & 0.656 \\
\hline SUI & no & no & $-1.3 \%$ & 0.839 & $-0.2 \%$ & 0.970 & $1.0 \%$ & 0.868 & $-0.9 \%$ & 0.323 \\
\hline AUT & no & no & $1.7 \%$ & 0.800 & $-5.0 \%$ & 0.434 & $-7.1 \%$ & 0.303 & $1.2 \%$ & 0.348 \\
\hline \multicolumn{11}{|c|}{ Energy-related standards/voluntary agreements } \\
\hline GER & yes & yes & $-2.2 \%$ & 0.735 & $0.6 \%$ & 0.816 & $1.9 \%$ & 0.632 & $-0.8 \%$ & 0.467 \\
\hline SUI & yes & yes & $5.2 \%$ & 0.591 & $-3.6 \%$ & 0.454 & $-11.3 \%$ & 0.306 & $1.2 \%$ & 0.106 \\
\hline AUT & yes & yes & $-13.0 \%$ & 0.335 & $4.9 \%$ & 0.696 & $15.4 \%$ & 0.146 & $-0.7 \%$ & 0.483 \\
\hline GER & yes & no & $-0.8 \%$ & 0.895 & $0.6 \%$ & 0.813 & $1.5 \%$ & 0.684 & $-0.1 \%$ & 0.895 \\
\hline SUI & yes & no & $-3.4 \%$ & 0.668 & $-0.5 \%$ & 0.920 & $2.1 \%$ & 0.746 & $0.3 \%$ & 0.891 \\
\hline AUT & yes & no & $12.9 \%$ & $0.016^{* *}$ & $9.7 \%$ & 0.265 & $3.7 \%$ & 0.672 & $-0.2 \%$ & 0.897 \\
\hline GER & no & yes & $1.1 \%$ & 0.768 & $1.4 \%$ & 0.482 & $1.7 \%$ & 0.577 & $0.8 \%$ & 0.346 \\
\hline SUI & no & yes & $-1.0 \%$ & 0.853 & $-2.7 \%$ & 0.449 & $-3.2 \%$ & 0.507 & $0.1 \%$ & 0.932 \\
\hline AUT & no & yes & $6.6 \%$ & 0.184 & $2.5 \%$ & 0.697 & $-0.9 \%$ & 0.898 & $-0.6 \%$ & 0.626 \\
\hline GER & no & no & $-1.3 \%$ & 0.698 & $-1.0 \%$ & 0.553 & $-1.1 \%$ & 0.662 & $-0.3 \%$ & 0.582 \\
\hline SUI & no & no & $5.6 \%$ & 0.250 & $3.3 \%$ & 0.388 & $1.3 \%$ & 0.801 & $-0.2 \%$ & 0.833 \\
\hline AUT & no & no & $18.5 \%$ & $0.000 * * *$ & & 0.738 & $-5.6 \%$ & 0.564 & $-0.5 \%$ & 0.716 \\
\hline \multicolumn{11}{|c|}{ Subsidies for energy technologies } \\
\hline GER & yes & yes & $5.2 \%$ & 0.269 & $3.0 \%$ & 0.277 & $2.6 \%$ & 0.512 & $0.9 \%$ & 0.645 \\
\hline SUI & yes & yes & $2.2 \%$ & 0.684 & $2.2 \%$ & 0.579 & $1.2 \%$ & 0.802 & $2.5 \%$ & $0.054 *$ \\
\hline AUT & yes & yes & $-15.4 \%$ & $0.035^{* *}$ & $0.7 \%$ & 0.913 & $10.8 \%$ & 0.126 & $0.0 \%$ & 0.978 \\
\hline GER & yes & no & $-2.5 \%$ & 0.631 & $-0.2 \%$ & 0.933 & $0.4 \%$ & 0.919 & $-0.5 \%$ & 0.417 \\
\hline SUI & yes & no & $4.0 \%$ & 0.553 & $6.3 \%$ & 0.208 & $7.6 \%$ & 0.182 & $0.1 \%$ & 0.960 \\
\hline AUT & yes & no & $10.8 \%$ & 0.178 & $-15.1 \%$ & 0.170 & $-22.1 \%$ & $0.083^{*}$ & $-1.6 \%$ & $0.015^{* *}$ \\
\hline GER & no & yes & $-0.7 \%$ & 0.842 & $1.3 \%$ & 0.471 & $2.8 \%$ & 0.301 & $0.9 \%$ & $0.073^{*}$ \\
\hline SUI & no & yes & $0.9 \%$ & 0.846 & $-0.9 \%$ & 0.778 & $-0.1 \%$ & 0.977 & $-1.2 \%$ & 0.262 \\
\hline AUT & no & yes & $16.7 \%$ & $0.000 * * *$ & $-2.8 \%$ & 0.739 & $-12.1 \%$ & 0.180 & $-1.8 \%$ & 0.357 \\
\hline GER & no & no & $0.7 \%$ & 0.842 & $-0.1 \%$ & 0.947 & $-0.5 \%$ & 0.859 & $-0.2 \%$ & 0.754 \\
\hline SUI & no & no & $2.6 \%$ & 0.581 & $2.2 \%$ & 0.540 & $2.3 \%$ & 0.622 & $-0.5 \%$ & 0.565 \\
\hline AUT & no & no & $10.8 \%$ & 0.051 & $-7.0 \%$ & 0.313 & $-13.1 \%$ & $0.086^{*}$ & $0.7 \%$ & 0.726 \\
\hline
\end{tabular}




\begin{tabular}{|c|c|c|c|c|c|c|c|}
\hline Country & $\begin{array}{l}\text { Energy } \\
\text { policy }\end{array}$ & $\begin{array}{l}\text { Effi- } \\
\text { ciency } \\
\text { result }\end{array}$ & $\begin{array}{r}\text { Export act } \\
\text { Effect }\end{array}$ & $\begin{array}{l}\text { tivity in } \mathrm{t} \\
\text { sign. }\end{array}$ & $\begin{array}{l}\text { Export share in } \mathrm{t} \\
\text { (all firms) } \\
\text { Effect sign. }\end{array}$ & $\begin{array}{l}\text { Export share in } \mathrm{t} \\
\text { (exporters only) } \\
\text { Effect sign. }\end{array}$ & $\begin{array}{l}\text { Change in export } \\
\text { share betw. } t-2 \text { and t } \\
\text { Effect sign. }\end{array}$ \\
\hline \multicolumn{8}{|c|}{ Demand for energy-efficient products } \\
\hline GER & yes & yes & $-10.0 \%$ & 0.106 & $-3.4 \% \quad 0.139$ & $0.2 \% \quad 0.954$ & $-0.5 \% \quad 0.373$ \\
\hline SUI & yes & yes & $9.7 \%$ & 0.330 & $3.0 \% \quad 0.728$ & $-3.2 \% \quad 0.804$ & $1.8 \% \quad 0.146$ \\
\hline AUT & yes & yes & $-34.5 \%$ & $0.057 *$ & $-13.2 \% \quad 0.206$ & $6.1 \% \quad 0.383$ & $-1.4 \% \quad 0.039 * *$ \\
\hline GER & yes & no & $7.6 \%$ & 0.160 & $0.0 \% \quad 0.985$ & $\begin{array}{ll}-4.5 \% & 0.113 \\
\end{array}$ & $0.6 \% \quad 0.306$ \\
\hline SUI & yes & no & $-4.5 \%$ & 0.514 & $0.1 \% \quad 0.990$ & $4.1 \% \quad 0.578$ & $-2.2 \% \quad 0.281$ \\
\hline AUT & yes & no & $13.9 \%$ & $0.001 * * *$ & $9.5 \% \quad 0.580$ & 0.907 & $-2.1 \% \quad 0.131$ \\
\hline GER & no & yes & $2.7 \%$ & 0.412 & $1.8 \% \quad 0.328$ & $1.4 \% \quad 0.589$ & $\begin{array}{ll}1.1 \% & 0.129\end{array}$ \\
\hline SUI & no & yes & $1.0 \%$ & 0.839 & $-1.0 \% \quad 0.759$ & $-2.3 \% \quad 0.610$ & $0.5 \% \quad 0.639$ \\
\hline AUT & no & yes & $2.0 \%$ & 0.740 & $1.6 \% \quad 0.815$ & $0.7 \% \quad 0.924$ & $-0.1 \% \quad 0.883$ \\
\hline GER & no & no & $-1.5 \%$ & 0.655 & $\begin{array}{ll}-0.2 \% & 0.897\end{array}$ & $\begin{array}{ll}0.5 \% & 0.844\end{array}$ & $\begin{array}{ll}-0.5 \% & 0.383 \\
\end{array}$ \\
\hline SUI & no & no & $3.4 \%$ & 0.459 & $2.3 \% \quad 0.506$ & 0.862 & $1.0 \% \quad 0.523$ \\
\hline AUT & no & no & $12.4 \%$ & $0.051 *$ & $\begin{array}{ll}-3.1 \% & 0.681\end{array}$ & $-9.4 \%$ & 0.280 \\
\hline
\end{tabular}

$* * *, * *, *$ : significant at the $0.01,0.05,0.1$ level. 
Table 14: Matching results on export performance by combinations of energy policy relevance and efficiency results of energy technology adoption, by country

\begin{tabular}{|c|c|c|c|c|c|c|c|c|c|c|}
\hline \multirow{3}{*}{\multicolumn{2}{|c|}{$\begin{array}{cc}\text { Country } & \begin{array}{l}\text { Energy } \\
\text { policy }\end{array} \\
\text { Energy taxes } \\
\end{array}$}} & \multirow[t]{2}{*}{$\begin{array}{l}\text { Effi- } \\
\text { ciency } \\
\text { result }\end{array}$} & \multicolumn{2}{|c|}{$\begin{array}{l}\text { Export activity in } \mathrm{t} \\
\text { Effect sign. }\end{array}$} & \multicolumn{2}{|c|}{$\begin{array}{l}\text { Export share in } \mathrm{t} \\
\text { (all firms) } \\
\text { Effect sign. }\end{array}$} & \multicolumn{2}{|c|}{$\begin{array}{l}\text { Export share in } \mathrm{t} \\
\text { (exporters only) } \\
\text { Effect sign. }\end{array}$} & \multicolumn{2}{|c|}{$\begin{array}{l}\text { Change in export } \\
\text { share betw. } \mathrm{t}-2 \text { and } \mathrm{t} \\
\text { Effect sign. }\end{array}$} \\
\hline & & & & & & & & & & \\
\hline & & yes & $-1.6 \%$ & 0.726 & $0.4 \%$ & 0.834 & $2.0 \%$ & 0.463 & $0.0 \%$ & 0.971 \\
\hline SUI & yes & yes & $9.5 \%$ & 0.217 & $6.5 \%$ & 0.194 & $4.0 \%$ & 0.446 & $-0.2 \%$ & 0.823 \\
\hline AUT & yes & yes & $3.6 \%$ & 0.463 & $-3.7 \%$ & 0.618 & $-6.0 \%$ & 0.480 & $-0.5 \%$ & 0.689 \\
\hline GER & yes & no & $4.8 \%$ & 0.286 & $1.6 \%$ & 0.545 & $0.7 \%$ & 0.876 & $0.2 \%$ & 0.644 \\
\hline SUI & yes & no & $9.9 \%$ & 0.194 & $-0.6 \%$ & 0.898 & $-8.6 \%$ & 0.188 & $-0.6 \%$ & 0.898 \\
\hline AUT & yes & no & $-10.2 \%$ & 0.376 & $10.9 \%$ & 0.311 & $20.8 \%$ & $0.008 * * *$ & $4.8 \%$ & 0.198 \\
\hline GER & no & yes & $-0.5 \%$ & 0.917 & $-0.1 \%$ & 0.972 & $0.1 \%$ & 0.989 & $-0.7 \%$ & 0.725 \\
\hline SUI & no & yes & $2.6 \%$ & 0.675 & $2.6 \%$ & 0.643 & $3.0 \%$ & 0.662 & $2.6 \%$ & 0.643 \\
\hline AUT & no & yes & $-3.5 \%$ & 0.738 & $-1.4 \%$ & 0.873 & $0.4 \%$ & 0.966 & $-0.5 \%$ & 0.564 \\
\hline GER & no & no & $-7.4 \%$ & 0.299 & $-2.7 \%$ & 0.359 & $-1.5 \%$ & 0.704 & $3.5 \%$ & 0.260 \\
\hline SUI & no & no & $-0.3 \%$ & 0.972 & $-4.0 \%$ & 0.519 & $-4.8 \%$ & 0.634 & $-4.0 \%$ & 0.519 \\
\hline AUT & no & no & $8.3 \%$ & 0.485 & $-7.2 \%$ & 0.501 & $-15.4 \%$ & 0.230 & $2.6 \%$ & 0.158 \\
\hline \multicolumn{11}{|c|}{ Energy-related regulation } \\
\hline GER & yes & yes & $-6.7 \%$ & 0.172 & $0.0 \%$ & 0.986 & $4.1 \%$ & 0.242 & $1.0 \%$ & 2.000 \\
\hline SUI & yes & yes & $3.5 \%$ & 0.659 & $-1.1 \%$ & 0.817 & $-5.6 \%$ & 0.472 & $0.6 \%$ & 0.450 \\
\hline AUT & yes & yes & $-8.8 \%$ & 0.531 & $-9.0 \%$ & 0.260 & $-6.6 \%$ & 0.412 & $0.1 \%$ & 0.940 \\
\hline GER & yes & no & $-5.8 \%$ & 0.281 & $0.5 \%$ & 0.875 & $3.9 \%$ & 0.431 & $0.9 \%$ & 0.143 \\
\hline SUI & yes & no & $6.6 \%$ & 0.290 & $5.8 \%$ & 0.216 & $4.9 \%$ & 0.384 & $5.8 \%$ & 0.216 \\
\hline AUT & yes & no & $-11.6 \%$ & 0.462 & $7.7 \%$ & 0.639 & $17.3 \%$ & 0.173 & $-1.9 \%$ & 0.269 \\
\hline GER & no & yes & $3.7 \%$ & 0.290 & $-0.2 \%$ & 0.900 & $-2.1 \%$ & 0.420 & $-0.4 \%$ & 0.540 \\
\hline SUI & no & yes & $4.8 \%$ & 0.332 & $0.8 \%$ & 0.820 & $-1.9 \%$ & 0.702 & $0.8 \%$ & 0.820 \\
\hline AUT & no & yes & $5.4 \%$ & 0.332 & $-1.1 \%$ & 0.855 & $-4.4 \%$ & 0.507 & $-2.2 \%$ & 0.123 \\
\hline GER & no & no & $0.7 \%$ & 0.855 & $-1.9 \%$ & 0.346 & $-4.1 \%$ & 0.216 & $0.5 \%$ & 0.495 \\
\hline SUI & no & no & $-1.0 \%$ & 0.877 & $-4.4 \%$ & 0.313 & $-5.8 \%$ & 0.397 & $-4.4 \%$ & 0.313 \\
\hline AUT & no & no & $3.9 \%$ & 0.718 & $5.4 \%$ & 0.632 & $4.3 \%$ & 0.724 & $3.1 \%$ & 0.115 \\
\hline \multicolumn{11}{|c|}{ Energy-related standards/voluntary agreements } \\
\hline GER & yes & yes & $1.0 \%$ & 0.866 & $-0.1 \%$ & 0.972 & $-0.2 \%$ & 0.956 & $-0.7 \%$ & 0.235 \\
\hline SUI & yes & yes & $-0.8 \%$ & 0.925 & $0.7 \%$ & 0.907 & $1.1 \%$ & 0.908 & $0.6 \%$ & 0.383 \\
\hline AUT & yes & yes & $-7.7 \%$ & 0.646 & $-4.6 \%$ & 0.649 & $-1.7 \%$ & 0.875 & $2.1 \%$ & 0.546 \\
\hline GER & yes & no & $1.1 \%$ & 0.848 & $1.9 \%$ & 0.543 & $1.9 \%$ & 0.665 & $0.7 \%$ & 0.145 \\
\hline SUI & yes & no & $-4.9 \%$ & 0.517 & $0.0 \%$ & 0.999 & $5.5 \%$ & 0.462 & $0.0 \%$ & 0.999 \\
\hline AUT & yes & no & $-6.1 \%$ & 0.606 & $2.8 \%$ & 0.817 & $7.4 \%$ & 0.570 & $1.7 \%$ & 0.436 \\
\hline GER & no & yes & $-1.4 \%$ & 0.674 & $-0.6 \%$ & 0.697 & $-0.7 \%$ & 0.772 & $-0.6 \%$ & 0.460 \\
\hline SUI & no & yes & $6.9 \%$ & 0.110 & $4.7 \%$ & 0.170 & $2.6 \%$ & 0.569 & $4.7 \%$ & 0.170 \\
\hline AUT & no & yes & $9.3 \%$ & $0.076^{*}$ & $-0.3 \%$ & 0.959 & $-5.5 \%$ & 0.381 & $-1.6 \%$ & 0.151 \\
\hline GER & no & no & $0.8 \%$ & 0.843 & $-0.2 \%$ & 0.908 & $-0.9 \%$ & 0.793 & $1.1 \%$ & 0.227 \\
\hline SUI & no & no & $9.2 \%$ & 0.102 & $-1.9 \%$ & 0.634 & $-9.0 \%$ & 0.115 & $-1.9 \%$ & 0.634 \\
\hline AUT & no & no & $-4.2 \%$ & 0.695 & $0.9 \%$ & 0.923 & $3.9 \%$ & 0.680 & $4.8 \%$ & 0.160 \\
\hline \multicolumn{11}{|c|}{ Subsidies for energy technologies } \\
\hline GER & yes & yes & $-2.3 \%$ & 0.719 & $-1.5 \%$ & 0.524 & $-2.0 \%$ & 0.576 & $0.9 \%$ & 0.588 \\
\hline SUI & yes & yes & $3.9 \%$ & 0.536 & $5.5 \%$ & 0.247 & $5.2 \%$ & 0.305 & $-0.4 \%$ & 0.796 \\
\hline AUT & yes & yes & $-21.1 \%$ & 0.135 & $-2.1 \%$ & 0.821 & $11.9 \%$ & $0.066^{*}$ & $-1.7 \%$ & 0.143 \\
\hline GER & yes & no & $2.0 \%$ & 0.687 & $0.7 \%$ & 0.792 & $-0.6 \%$ & 0.871 & $-0.1 \%$ & 0.919 \\
\hline SUI & yes & no & $3.7 \%$ & 0.711 & $2.4 \%$ & 0.711 & $1.3 \%$ & 0.900 & $2.4 \%$ & 0.711 \\
\hline AUT & yes & no & $-10.7 \%$ & 0.380 & $5.4 \%$ & 0.645 & $15.2 \%$ & 0.194 & $1.2 \%$ & 0.504 \\
\hline GER & no & yes & $-1.5 \%$ & 0.657 & $0.1 \%$ & 0.944 & $1.1 \%$ & 0.637 & $-0.1 \%$ & 0.815 \\
\hline SUI & no & yes & $2.6 \%$ & 0.549 & $1.8 \%$ & 0.578 & $1.6 \%$ & 0.709 & $1.8 \%$ & 0.578 \\
\hline AUT & no & yes & $5.9 \%$ & 0.491 & $-3.2 \%$ & 0.629 & $-7.4 \%$ & 0.247 & $-0.9 \%$ & 0.532 \\
\hline GER & no & no & $3.1 \%$ & 0.430 & $-0.9 \%$ & 0.648 & $-3.2 \%$ & 0.278 & $0.1 \%$ & 0.831 \\
\hline SUI & no & no & $7.5 \%$ & 0.219 & $2.8 \%$ & 0.564 & $2.0 \%$ & 0.752 & $2.8 \%$ & 0.564 \\
\hline AUT & no & no & $13.0 \%$ & $0.016^{* *}$ & $13.8 \%$ & 0.216 & $7.9 \%$ & 0.487 & $4.2 \%$ & 0.143 \\
\hline
\end{tabular}




\begin{tabular}{|c|c|c|c|c|c|c|c|}
\hline Country & $\begin{array}{l}\text { Energy } \\
\text { policy }\end{array}$ & $\begin{array}{l}\text { Effi- } \\
\text { ciency } \\
\text { result }\end{array}$ & $\begin{array}{r}\text { Export act } \\
\text { Effect }\end{array}$ & $\begin{array}{l}\text { tivity in } t \\
\text { sign. }\end{array}$ & $\begin{array}{l}\text { Export share in } \mathrm{t} \\
\text { (all firms) } \\
\text { Effect sign. }\end{array}$ & $\begin{array}{l}\text { Export share in } \mathrm{t} \\
\text { (exporters only) } \\
\text { Effect sign. }\end{array}$ & $\begin{array}{l}\text { Change in export } \\
\text { share betw. } t-2 \text { and t } \\
\text { Effect sign. }\end{array}$ \\
\hline \multicolumn{8}{|c|}{ Demand for energy-efficient products } \\
\hline GER & yes & yes & $-3.7 \%$ & 0.533 & $-1.8 \% \quad 0.395$ & $-1.6 \% \quad 0.607$ & $-0.4 \% \quad 0.325$ \\
\hline SUI & yes & yes & $-0.7 \%$ & 0.936 & $-4.7 \% \quad 0.266$ & $-9.1 \% \quad 0.224$ & $0.1 \% \quad 0.875$ \\
\hline AUT & yes & yes & $-34.1 \%$ & $0.040^{* *}$ & $-12.5 \% \quad 0.180$ & $6.4 \% \quad 0.306$ & $-1.6 \% \quad 0.030 * *$ \\
\hline GER & yes & no & $0.9 \%$ & 0.890 & $1.0 \% \quad 0.696$ & $1.5 \% \quad 0.696$ & $1.4 \% \quad 0.035^{* *}$ \\
\hline SUI & yes & no & $5.9 \%$ & 0.522 & $-0.1 \% \quad 0.993$ & $-4.4 \% \quad 0.634$ & $-0.1 \% \quad 0.993$ \\
\hline AUT & yes & no & $7.3 \%$ & 0.345 & $13.1 \% \quad 0.393$ & $10.4 \%$ & $-1.1 \% \quad 0.415$ \\
\hline GER & no & yes & $-0.4 \%$ & 0.891 & $1.0 \% \quad 0.517$ & $2.0 \%$ & $-0.2 \% \quad 0.700$ \\
\hline SUI & no & yes & $4.4 \%$ & 0.307 & $3.0 \% \quad 0.349$ & $0.3 \% \quad 0.950$ & $3.0 \% \quad 0.349$ \\
\hline AUT & no & yes & $7.8 \%$ & 0.159 & $3.2 \% \quad 0.633$ & $-0.9 \% \quad 0.899$ & $-1.4 \% \quad 0.260$ \\
\hline GER & no & no & $-0.8 \%$ & 0.831 & $\begin{array}{ll}-1.2 \% & 0.541 \\
\end{array}$ & $-2.0 \%$ & $\begin{array}{lll}0.4 \% & 0.559\end{array}$ \\
\hline SUI & no & no & $4.4 \%$ & 0.401 & $-1.2 \% \quad 0.745$ & $-3.7 \%$ & $-1.2 \% \quad 0.745$ \\
\hline AUT & no & no & $2.7 \%$ & 0.780 & $9.0 \% \quad 0.467$ & 0.493 & $3.9 \% \quad 0.170$ \\
\hline
\end{tabular}

$* * *, * *, *$ : significant at the $0.01,0.05,0.1$ level. 